\title{
Light availability in the coastal ocean: impact on the distribution of benthic photosynthetic organisms and their contribution to primary production
}

\author{
J.-P. Gattuso ${ }^{1}$, B. Gentili ${ }^{1}$, C. M. Duarte ${ }^{2}$, J. A. Kleypas ${ }^{3}$, J. J. Middelburg ${ }^{4}$, and D. Antoine ${ }^{1}$ \\ ${ }^{1}$ CNRS, Laboratoire d'océanographie de Villefranche, 06234 Villefranche-sur-Mer Cedex, France; Université Pierre et Marie \\ Curie-Paris6, Laboratoire d'océanographie de Villefranche, 06234 Villefranche-sur-Mer Cedex, France \\ ${ }^{2}$ Instituto Mediterraneo de Estudios Avanzados, CSIC-UIB, C/ Miquel Marqués 21, 07190 Esporles, Spain \\ ${ }^{3}$ National Center for Atmospheric Research, P.O. Box 3000, Boulder, CO 80307-3000, USA \\ ${ }^{4}$ Netherlands Institute of Ecology, P.O. Box 140, 4400 AC Yerseke, The Netherlands
}

Received: 2 June 2006 - Published in Biogeosciences Discuss.: 12 July 2006

Revised: 30 October 2006 - Accepted: 31 October 2006 - Published: 6 November 2006

\begin{abstract}
One of the major features of the coastal zone is that part of its sea floor receives a significant amount of sunlight and can therefore sustain benthic primary production by seagrasses, macroalgae, microphytobenthos and corals. However, the contribution of benthic communities to the primary production of the global coastal ocean is not known, partly because the surface area where benthic primary production can proceed is poorly quantified. Here, we use a new analysis of satellite (SeaWiFS) data collected between 1998 and 2003 to estimate, for the first time at a nearly global scale, the irradiance reaching the bottom of the coastal ocean. The following cumulative functions provide the percentage of the surface $(S)$ of the coastal zone receiving an irradiance greater than $E_{z}$ (in mol photons $\mathrm{m}^{-2} \mathrm{~d}^{-1}$ ):

$S_{\text {Non-polar }}=29.61-17.92 \log _{10}\left(E_{z}\right)+0.72 \log _{10}^{2}\left(E_{z}\right)+0.90 \log _{10}^{3}\left(E_{z}\right)$

$S_{\text {Arctic }}=15.99-13.56 \log _{10}\left(E_{z}\right)+1.49 \log _{10}^{2}\left(E_{z}\right)+0.70 \log _{10}^{3}\left(E_{z}\right)$
\end{abstract}

Data on the constraint of light availability on the major benthic primary producers and net community production are reviewed. Some photosynthetic organisms can grow deeper than the nominal bottom limit of the coastal ocean $(200 \mathrm{~m})$. The minimum irradiance required varies from 0.4 to 5.1 mol photons $\mathrm{m}^{-2} \mathrm{~d}^{-1}$ depending on the group considered. The daily compensation irradiance of benthic communities ranges from 0.24 to $4.4 \mathrm{~mol}$ photons $\mathrm{m}^{-2} \mathrm{~d}^{-1}$. Data on benthic irradiance and light requirements are combined to estimate the surface area of the coastal ocean where (1) light does not limit the distribution of primary producers and (2) net community production ( $N C P$, the balance between gross primary production and community respiration) is positive.

Correspondence to: J.-P. Gattuso

(gattuso@obs-vlfr.fr)
Positive benthic NCP can occur over $33 \%$ of the global shelf area. The limitations of this approach, related to the spatial resolution of the satellite data, the parameterization used to convert reflectance data to irradiance, the lack of global information on the benthic nepheloid layer, and the relatively limited biological information available, are discussed.

\section{Introduction}

Sunlight is by far the major energy source for electron transport leading to marine primary production. One of the major features of the coastal zone is that part of its sea floor receives a significant amount of sunlight. Ackleson (2003) made a strong case that light in the shallow ocean should receive much more attention than it presently does.

One compelling reason to examine light in coastal environments is that penetration of light to the sea floor sustains benthic primary production which contributes to total primary production. All benthic substrates receiving enough light to sustain primary production harbour photosynthetic organisms, both conspicuous such as seagrasses, algae and corals, and less conspicuous such as the microflora thriving in sandy and muddy bottoms. In some coastal ecosystems, such as coral reefs and macrophyte-dominated ecosystems, benthic primary production contributes $90 \%$ or more to total carbon fixation (e.g., Delesalle et al., 1993; Borum and Sand-Jensen, 1996). Benthic microalgae can also contribute significantly to total primary production (e.g., Cahoon et al., 1993; Jahnke et al., 2000; McMinn et al., 2005). The role of marine vegetation in the global marine carbon cycle has recently been revised (Duarte et al., 2005). Burial in vegetated habitats contributes about half of the total carbon burial in

Published by Copernicus GmbH on behalf of the European Geosciences Union. 
the ocean (Duarte et al., 2005) and fuels a sizable portion of respiration in adjacent coastal and offshore ecosystems (Middelburg et al., 2005). However, the contribution of benthic communities to the primary production of the global coastal ocean is not known, in part because the surface area where benthic primary production can proceed is poorly quantified. Estimating it requires the combination of knowledge on the light requirements of benthic primary producers with information on underwater light penetration.

Some regional estimates of the continental shelf area that contributes to benthic marine primary production are available. Cahoon et al. (1993) used Secchi disk depths to estimate that $16 \%$ of the stations with depths of $200 \mathrm{~m}$ or less receive more than $1 \%$ of the incident light and that an additional $16 \%$ receive more than $0.1 \%$ of incident irradiance. Assuming that these data are evenly distributed and extending them to the global coastal zone suggests that approximately $30 \%$ of the continental shelf sea floor receives enough light to support primary production (Jahnke, 2005). There is, however, no current estimate of the area of the continental shelf that contributes to marine primary production based on a large-scale analysis.

Ocean color satellite-borne sensors have the potential to provide an estimate of light penetration in the water column through a relationship between the blue-to green reflectance ratio, measured by satellites such as the Coastal Zone Color Scanner (CZCS) and the Sea-viewing Wide Field-of-view Sensor (SeaWiFS), and attenuation in the water column estimated by $K_{\mathrm{PAR}}$, the light attenuation coefficient of photosynthetically available radiation (PAR). It is usually assumed that $K_{\mathrm{PAR}}$ is related to the concentration of chlorophyll-a, itself derived from reflectance values. This approach is now routinely used in the open ocean (Case 1 waters) where phytoplankton is the main contributor to attenuation (but see Claustre and Maritorena, 2003). The use of similar relationships is, however, not straightforward in the coastal ocean where light attenuation by colored dissolved organic matter and suspended particles other than phytoplankton can be significant (Case 2 waters).

This paper has two objectives: quantify the light reaching the sea bottom and assess the consequences for the distribution of benthic photosynthetic organisms and coastal metabolism. A three-steps approach is used. First, the SeaWiFS data collected between 1998 and 2003 are analyzed to estimate the irradiance reaching the bottom of the coastal ocean. Second, data on the constraint of light availability on the major benthic primary producers and on net community production are compiled. Finally, the two data sets are combined to derive estimates of the surface area where (1) light does not limit the distribution of primary producers and (2) net community production (the balance between gross primary production and community respiration) is positive.

\section{Methods}

\subsection{Determination of the coastal zone}

Surface areas and average depths were estimated from the ETOPO2 global relief data set downloaded from the National Geophysical Data Center (http://www.ngdc.noaa.gov/mgg/ fliers/01mgg04.html) and the Generic Mapping Tools (GMT; Wessel and Smith, 1998). The ETOPO2 data set blends satellite altimetry with ocean soundings and new land data to provide a global elevation and bathymetry on a $2^{\prime} \times 2^{\prime}$ grid. Subsequent to the data processing reported in the present paper, a registration error was reported for this data set (Marks and Smith, 2006). This magnitude of this error not constant everywhere over the Earth (W. H. F. Smith, personal communication). Its North-South component may be a function of latitude whereas the East-West component may be a constant angle. The effect on the regional and global estimates presented in the present study are small, but we acknowledge that the incorrect registration of depths could affect estimates across smaller areas. Pixels with a depth ranging from 0 to $200 \mathrm{~m}$ were considered.

Continental shelf regions were divided into three geographical zone: Arctic (latitudes greater than $60^{\circ} \mathrm{N}$ ), Antarctic (latitudes lower than $60^{\circ} \mathrm{S}$ ), and the non-polar region $\left(60^{\circ} \mathrm{N}\right.$ to $\left.60^{\circ} \mathrm{S}\right)$. About $4 \%$ of the surface of the Arctic and Antarctic zones could not be used due to discrepancies between the ETOPO2 data set and the GMT coastline, and only $0.8 \%$ for the non-polar region. The Arctic, Antarctic, and non-polar regions represent, respectively, $24.1 \%, 1.8 \%$, and $74.1 \%$ of the total coastal surface covered. Figure 1 shows these three zones with the non-available pixels on the SeaWiFS composite image for the year 2000. Proximal coastal pixels are defined as pixels comprising a portion of the coastline; all other coastal pixels are defined as distal.

\subsection{SeaWiFS data}

There are several levels of SeaWiFS data, two of which were used in the present paper. Level-2 data are geophysical products such as the chlorophyll concentration or the diffuse attenuation coefficient, geographically referenced, and provided on an orbit per orbit (or scene by scene) basis at the spatial resolution of the satellite sensor. Level-3 data are averages of individual Level-2 data on a spatial grid (e.g., a $9 \mathrm{~km}$ global grid) and over a given time period (e.g., a month). Monthly and annual SeaWiFS Level-3 global composites were obtained from the NASA Goddard Space Flight Center DAAC, for the years 1998 to 2002. These data are organized on a $2048 \times 4096$ equirectangular projection with a constant latitude and longitude step (Campbell et al., 1995). The resolution at the equator is approximately $9 \mathrm{~km}$. Three SeaWiFS-derived quantities were used: the upperlayer chlorophyll-a concentration $\left(C_{\text {sat }}\right)$ derived through the OC4V4 algorithm (O'Reilly et al., 1998), the normalized 

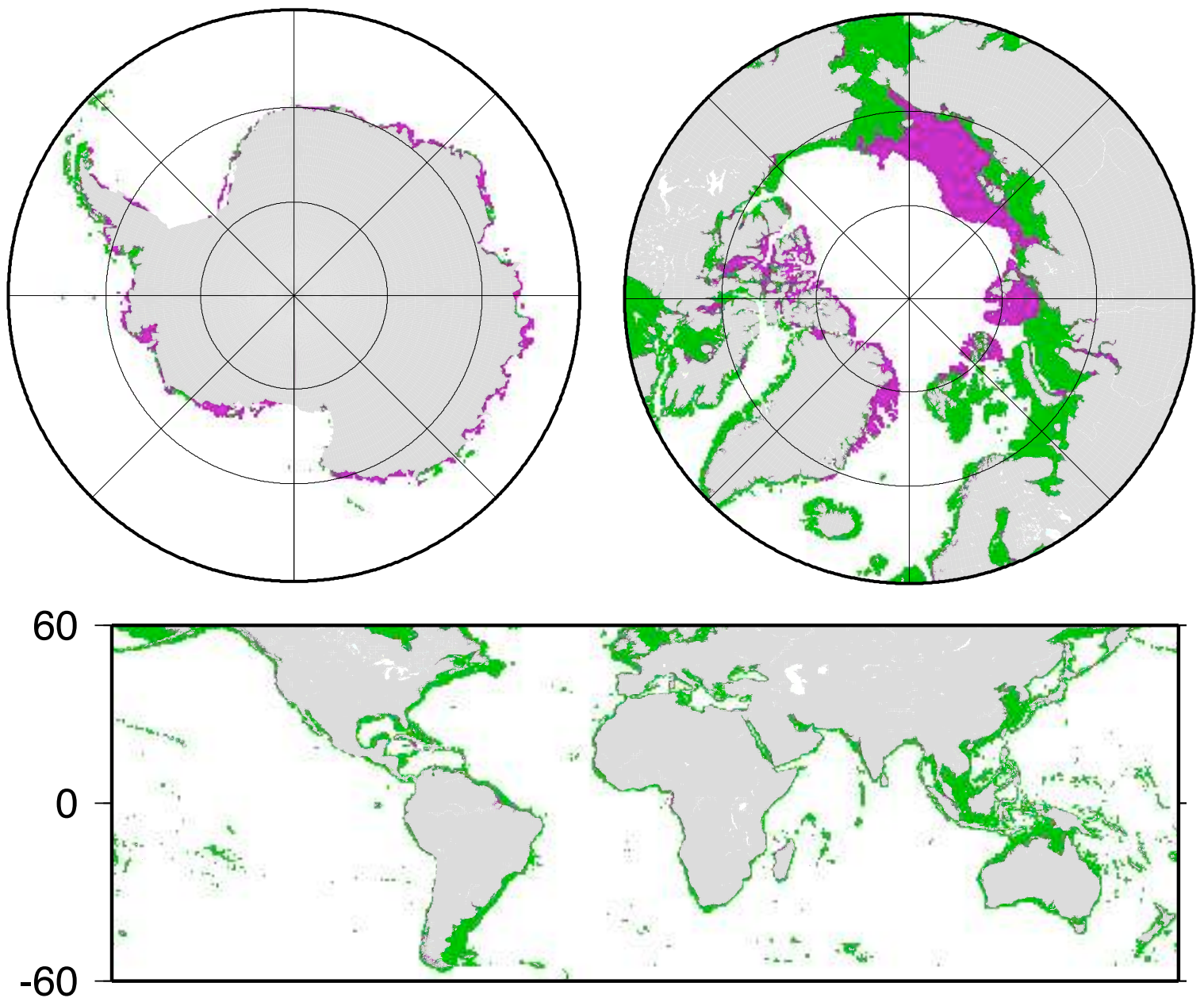

Fig. 1. The three geographical areas considered. Green and purple pixels are, respectively, pixels for which data are available or not on the SeaWiFS composite image for the year 2000.

water-leaving radiance at $555 \mathrm{~nm}, n L w(555)$, and the photosynthetically available radiation at the sea surface, $\operatorname{PAR}(0+)$, computed following Frouin et al. (2003). A given bin of these Level- 3 composites contains the arithmetic average of all individual Level-2 1-km pixels that passed a series of exclusion criteria (Robinson et al., 2003).

\subsection{Case 1 versus Case 2 waters}

It is beyond the scope of this paper to review the criteria used to eliminate dubious data when generating a SeaWiFS Level3 composite, except for discriminating the water type as either Case 1 or Case 2 (Morel and Prieur, 1977), as the latter type is well represented in coastal waters. The discrimination between these two types is performed at the Level-2 in the SeaWiFS processing, yet it is not considered when generating the Level-3 composites (B. Franz, personal communication). Therefore, the average chlorophyll-a concentration in a given bin of a Level-3 composite may have been computed over any proportion of Case 1 and Case 2 waters. The accuracy of $C_{\text {sat }}$ in Case 1 waters is claimed to be $\pm 30 \%$ whereas its is unknown in Case 2 waters. It is therefore not possible to estimate the accuracy of the chlorophyll product in coastal areas and, in turn, the accuracy of the diffuse attenuation coefficient. We apply an a posteriori determination of the water type based on the average $C_{\text {sat }}$ and $n L w(555)$ (see below), which is not based on specific algorithms for each water type (since no universal algorithm exists). This determination nevertheless provides an indication of bins of Case 2 water because, on average, the individual pixels in the bins were predominantly of the Case 2 type. Waters with a $C_{\text {sat }}$ value lower than $0.2 \mathrm{mg} \mathrm{m}^{-3}$ are considered to be Case 1 (A. Morel, personal communication). When $C_{\text {sat }}$ is higher than $0.2 \mathrm{mg} \mathrm{m}^{-3}$, the identification of turbid Case 2 waters is performed as in Morel and Bélanger (2006) by comparing the water reflectance at $555 \mathrm{~nm}(R(555))$ to the maximum value it should have in Case 1 waters $\left(R_{\lim }(555)\right)$. Turbid Case 2 waters are those for which $R(555)>R_{\lim }(555)$. To perform this test, the normalized water-leaving radiance, i.e., 
the SeaWiFS product, is converted into $R$ as follows (Morel and Gentili, 1996):

$R(555)=\frac{n L w(555) \times Q_{0}(555)}{F_{0}(555) \times \Re_{0}}$

where $F_{0}(555)$ is the extra-terrestrial irradiance at $555 \mathrm{~nm}$ (185.33 $\mathrm{W} \mathrm{m}^{-2} \mathrm{~nm}^{-1}$; Thuillier et al., 2003), $Q_{0}(555)$ is the chlorophyll-dependent $Q$-factor, i.e., the ratio of the upward irradiance to the upwelling radiance (Morel et al., 2002), and $\mathfrak{R}_{0}$ is a term which merges all reflection and refraction effects at the air-sea interface (0.529). Since $n L w$ is fully normalized (Morel and Gentili, 1996), its dependence on the viewing angle and the sun zenith angle are removed so that both $Q$ and $\Re$ are taken for a nadir view and a sun at zenith (hence the " 0 " subscript).

\subsection{Benthic irradiance}

The diffuse attenuation coefficient for the downwelling irradiance $\left(K_{D}\right)$ describes the exponential propagation of spectral irradiance with depth in the water column. It determines the amount of radiation reaching a given depth $(Z)$ and whether light reaches the sea bottom:

$K_{D}=\frac{-d\left[L N\left(E_{d}(\lambda, Z)\right)\right]}{d Z}$

The spectral composition of the radiation is not considered in this work and only its integral value between 400 and $700 \mathrm{~nm}$ is used (i.e., the photosynthetically available radiation, PAR). The mean attenuation coefficient for PAR $\left(K_{\mathrm{PAR}}\right)$ is therefore:

$K_{\mathrm{PAR}}=\frac{-d[L N(\operatorname{PAR}(Z))]}{d Z}$

The average value of $K_{\text {PAR }}$ over the euphotic zone was determined as described by Morel (1988):

$K_{\mathrm{PAR}}=0.121 \times C_{\mathrm{sat}}^{0.428}$

This relationship has been established for open ocean Case 1 waters. However, the sole piece of information available in a given bin is the monthly average chlorophyll-a concentration $\left(C_{\text {sat }}\right)$. This average may include relatively accurate chlorophyll-a concentrations determined in Case 1 waters and relatively inaccurate values determined in turbid Case 2 waters, the proportion of each being unknown. The impact on the computation of the diffuse attenuation coefficient is therefore unpredictable.

2.5 Comparison with $K_{\mathrm{PAR}}$ estimates derived from Secchi disk depths

Secchi disk depths $\left(Z_{s d}\right)$ were extracted from the World Ocean Database (Conkright et al., 1999). $Z_{s d}$ values are included in the secondary header information, and include observations taken from the early 1900s through the 1990s.
Several studies have produced formula for converting $Z_{s d}$ (in $\mathrm{m}$ ) to a light attenuation coefficient $\left(K_{\mathrm{PAR}}\right)$. The early formulae follow the general equation: $K_{\mathrm{PAR}}=q / Z_{s d}$, where $q$ is an empirically determined constant. For Case 1 waters, the value of $q$ was determined as 1.7 (Poole and Atkins, 1929; Idso and Gilbert, 1974), but for Case 2 waters $q$ was determined to be around 1.4 (Gall, 1949). For this study, we used two formulae: (1) that of Holmes (1970), where $K_{\mathrm{PAR}}=1.7 / Z_{s d}$ when $Z_{s d}<5 \mathrm{~m}$ and $K_{\mathrm{PAR}}=1.44$ when $Z_{s d}>5 \mathrm{~m}$; and (2) that of Weinberg (1976), where $K_{\mathrm{PAR}}=2.6 /\left(Z_{s d}+2.5\right)-0.048$.

The Secchi-derived $K_{\mathrm{PAR}}$ values were averaged for each SeaWiFS gridcell. For grid cells with at least 10 Secchi disk depth observations and water depths less than $200 \mathrm{~m}$, the average secchi-derived $K_{\mathrm{PAR}}$ values were compared to the av-

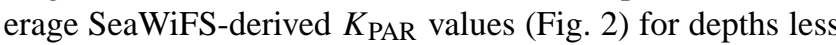
than $200 \mathrm{~m}$. The SeaWiFS-derived $K_{\mathrm{PAR}}$ values were consistently less than those derived from the Secchi disk depths, although use of the Weinberg (1976) formula produced slightly better correlations with the SeaWiFS data. Correlations were best in Case 2 waters, and decreased at higher $K_{\text {PAR values. }}$

\subsection{Compilation of data}

The minimum light requirements $\left(E_{\min }\right)$ of the major groups of photosynthetic organisms were compiled from the literature. The annual average irradiance at depth $\left(E_{z}\right)$ is not often reported but $K_{\mathrm{PAR}}$ or the percent surface irradiance $\left(\% E_{0}\right)$ often is. In such cases, $E_{\text {min }}$ was estimated from $K_{\mathrm{PAR}}$ or $\% E_{0}$ using the average daily surface irradiance provided by SeaWiFS. Irradiance data expressed in energy units were converted to molar units using a conversion factor of $2.5 \times 10^{18}$ quanta $\mathrm{s}^{-1}$ watt $^{-1}$ or $4.2 \mu \mathrm{mol}$ photons $\mathrm{m}^{-2} \mathrm{~s}^{-1}$ watt $^{-1}$ (Morel and Smith, 1974).

\section{Results}

This section is devoted to the analysis of the SeaWiFS data. The compilation of literature data on the constraints of light availability on the major primary producers and NCP is presented in the discussion section.

The Antarctic region is poorly covered by the SeaWiFS sensor due to limitations of the algorithms against sun-zenith angles, and to the presence of ice. Only $36 \%$ of the coastal zone is available in the annual images, and $26 \%$ are available in the best monthly image (February 2003). As this region only represents $1.8 \%$ of the surface area of the world coastal zone, it was not considered further in this analysis. Temporal variations for the Arctic and non-polar regions are shown in Fig. 3. Other data are summarized in Tables 1 and 2. Appendices $\mathrm{A}$ and $\mathrm{B}$ provide the gridded data of the geographical distribution of Case 1 and Case 2 waters as well as of benthic irradiance, respectively. 
Table 1. Surface area and average depth of the various pixel classes. $E_{z}=1 \%$ is the level at which benthic irradiance equals $1 \%$ of surface irradiance. Available pixels are those for which $C_{\text {sat }}, n L w(555)$ and PAR are available for analysis. Proximal coastal pixels are defined as pixels comprising a portion of the coastline; all other coastal pixels are defined as distal.

\begin{tabular}{|c|c|c|c|c|c|c|}
\hline & \multicolumn{3}{|c|}{ Arctic } & \multicolumn{3}{|c|}{ Non-polar } \\
\hline & \multicolumn{3}{|c|}{$\begin{array}{l}\text { Monthly images } \\
\text { (June-October) }\end{array}$} & \multicolumn{3}{|c|}{ Monthly images } \\
\hline & Min & $\operatorname{Max}$ & Mean & Min & $\operatorname{Max}$ & Mean \\
\hline Available pixels/total number of pixels & 0.20 & 0.60 & 0.39 & 0.68 & 0.90 & 0.81 \\
\hline Average depth available pixels (m) & 74 & 87 & 80 & 67 & 71 & 69 \\
\hline Case 1 pixels/available pixels & 0.58 & 0.72 & 0.66 & 0.46 & 0.65 & 0.55 \\
\hline Average depth Case 1 pixels (m) & 86 & 99 & 93 & 80 & 86 & 83 \\
\hline Case 2 pixels/available pixels & 0.28 & 0.42 & 0.34 & 0.35 & 0.54 & 0.45 \\
\hline Average depth Case 2 pixels & 43 & 70 & 55 & 44 & 57 & 52 \\
\hline Pixels $E_{z}=1 \%$ /available pixels & 0.20 & 0.29 & 0.25 & 0.35 & 0.41 & 0.37 \\
\hline Average depth pixels $E_{z}=1 \%(\mathrm{~m})$ & 14 & 18 & 16 & 21 & 24 & 22 \\
\hline Proximal pixels/available pixels & 0.07 & 0.10 & 0.08 & 0.19 & 0.47 & 0.30 \\
\hline Average depth proximal pixels (m) & 25 & 29 & 28 & 19 & 23 & 22 \\
\hline Distal pixels/available pixels & 0.90 & 0.93 & 0.92 & 0.53 & 0.81 & 0.70 \\
\hline \multirow[t]{3}{*}{ Average depth distal pixels (m) } & 70 & 77 & 73 & 43 & 74 & 63 \\
\hline & \multicolumn{3}{|c|}{ Annual images } & \multicolumn{3}{|c|}{ Annual images } \\
\hline & Min & Max & Mean & Min & Max & Mean \\
\hline Available pixels/total number of pixels & 0.67 & 0.68 & 0.68 & 0.96 & 0.96 & 0.96 \\
\hline Average depth available pixels (m) & 73.8 & 74.4 & 74 & 67.7 & 67.9 & 67.9 \\
\hline Case 1 pixels/available pixels & 0.65 & 0.69 & 0.67 & 0.53 & 0.57 & 0.55 \\
\hline Average depth Case 1 pixels (m) & 89.2 & 91.4 & 90.4 & 84.5 & 86.1 & 85.3 \\
\hline Case 2 pixels/available pixels & 0.31 & 0.35 & 0.33 & 0.43 & 0.47 & 0.45 \\
\hline Average depth Case 2 pixels (m) & 39.4 & 45.4 & 41.5 & 45.1 & 47.7 & 46.8 \\
\hline Pixels $E_{z}=1 \%$ /available pixels & 0.27 & 0.30 & 0.28 & 0.35 & 0.36 & 0.36 \\
\hline Average depth pixels $E_{z}=1 \%(\mathrm{~m})$ & 14.5 & 16.1 & 15.2 & 19.5 & 19.9 & 19.7 \\
\hline Proximal pixels/available pixels & 0.08 & 0.09 & 0.08 & 0.79 & 0.80 & 0.80 \\
\hline Average depth proximal pixels (m) & 26.5 & 27.7 & 27.3 & 19.4 & 19.7 & 19.5 \\
\hline Distal pixels/available pixels & 0.91 & 0.92 & 0.92 & 0.20 & 0.21 & 0.20 \\
\hline Average depth distal pixels (m) & 74.9 & 75.8 & 75.5 & 33.5 & 34.5 & 33.6 \\
\hline
\end{tabular}

Table 2. Surface area $(S)$ and average depth $(Z)$ of coastal waters of different optical characteristics.

\begin{tabular}{lcccccc}
\hline & \multicolumn{3}{c}{ Arctic } & \multicolumn{3}{c}{ Non-polar } \\
& $S\left(10^{6} \mathrm{~km}^{2}\right)$ & $S(\%)$ & $Z(\mathrm{~m})$ & $S\left(10^{6} \mathrm{~km}^{2}\right)$ & $S(\%)$ & $Z(\mathrm{~m})$ \\
\hline Coastal zone & 6.13 & 100 & 73.3 & 18.82 & 100 & 66 \\
\hline Monthly images & & & & & & \\
$\quad$ Case 1 & 1.6 & 26.2 & 92.8 & 8.47 & 45 & 83 \\
Case 2 & 0.81 & 13.2 & 54.6 & 6.76 & 35.9 & 52 \\
$\quad$ Cases 1 and 2 & 2.41 & 39.4 & 80 & 15.23 & 80.9 & 69 \\
\hline Annual images & & & & & & \\
$\quad$ Case 1 & 2.75 & 44.9 & 90.4 & 9.93 & 52.7 & 85 \\
$\quad$ Case 2 & 1.39 & 22.6 & 41.5 & 8.19 & 43.5 & 47 \\
$\quad$ Cases 1 and 2 & 4.14 & 67.5 & 74.1 & 18.11 & 96.2 & 68 \\
\hline
\end{tabular}



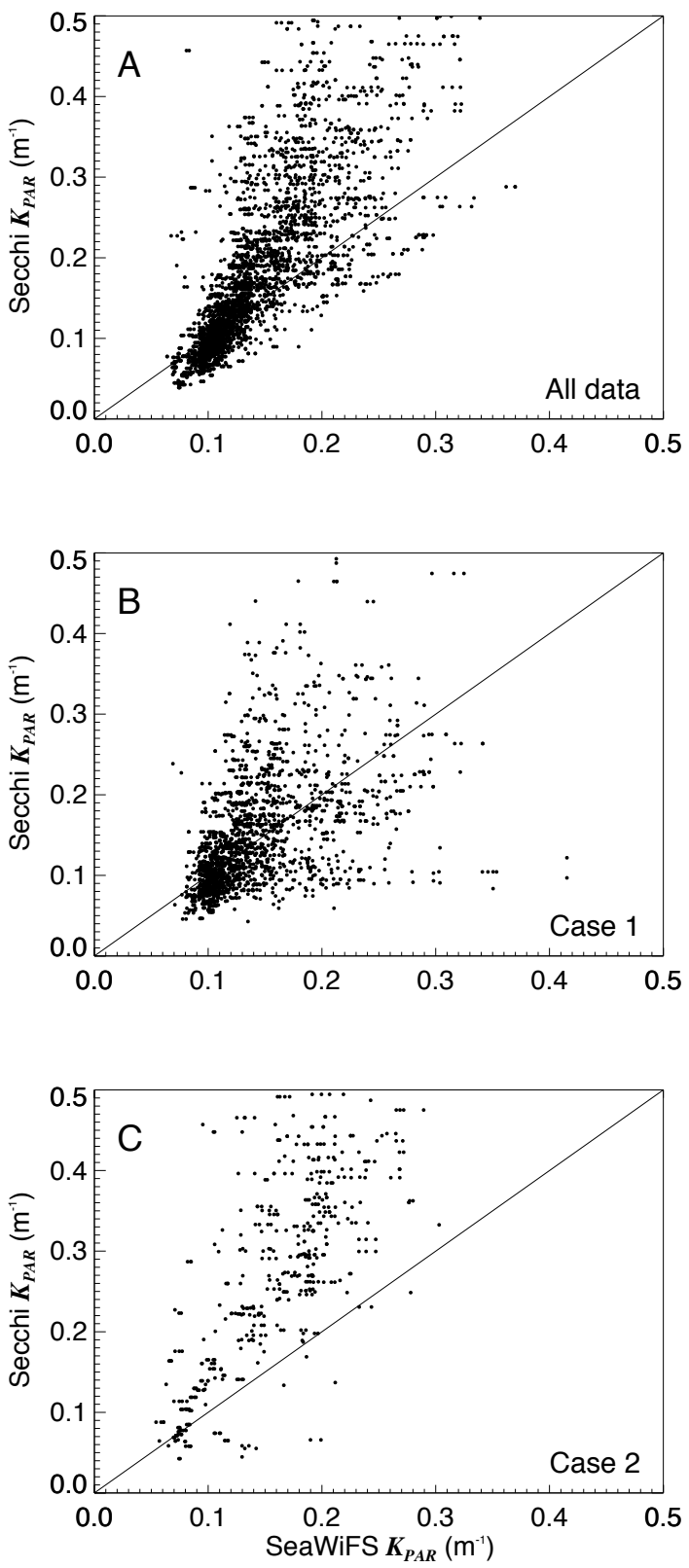

Fig. 2. $K_{\mathrm{PAR}}$ values derived from Secchi disk depth data using the formulation of Weinberg (1976) versus $K_{\text {PAR }}$ derived from SeaWiFS data. The 1:1 line is shown. Model II regressions are: $y=-0.023+1.43 \times x(N=3424 ; r=0.76)$ for all data, $y=0.022+0.87 \times x \quad(N=2126 ; r=0.51)$ for Case 1 waters, and $Y=0.002+1.68 \times x(N=467 ; r=0.73)$ for Case 2 waters. $N$ is the number of data and $r$ is the Pearson correlation coefficient. The slopes of the geometric regression forced through the origin are $1.25,1.05$ and 1.7 , respectively for all data, Case 1 waters and Case 2 waters. Note that correlations are not shown for locations where waters varied seasonally between Case 1 and Case 2 in the SeaWiFS calculations.

\subsection{Arctic region}

Data availability vary greatly with season in the Arctic region. In monthly images, the fraction of the coastal zone available for analysis ranged from 0 in winter (November, December and January) to less than 0.10 in February, March, April and May; these 7 months were therefore not further considered. The fraction of data available of the remaining 5 months ranges from 0.20 to 0.60 and is about 0.68 on annual images (Tables 1). From these data were calculated the fractions (of the available coastal zone) of: Case 1 waters $\left(f_{1}\right)$, Case 2 waters $\left(f_{2}\right)$, and the fraction of the coastal ocean where the bottom irradiance is more than $1 \%$ of the incident surface irradiance $\left(f_{1 \%}\right)$. On average, $f_{1}=0.66$ and $f_{2}=0.34$ on both annual and mean monthly images, $f_{1 \%}=0.25$ in monthly images and 0.28 in annual images, and $92 \%$ of the missing pixels are distal. Of course, the variability is greater on monthly images but, on average, the results are similar in monthly and annual images.

\subsection{Non-polar region}

In non-polar regions, the fraction of the total coastal zone surface area available for analysis was 0.96 in the annuallyaveraged images, and varied from 0.68 to 0.90 in the monthly images. On average, $f_{1}=0.55$ and $f_{2}=0.45$ on both monthly and annual images, and $f_{1 \%}=0.37$ (monthly) or 0.36 (annual). Aside from the variability, the main difference between monthly and annual images is the proximal/distal ratio of non-available pixels. The proximal/distal ratio is $0.30 / 0.70$ on monthly images and $0.80 / 0.20$ on annual images. This is because distal pixels, which are mainly affected by cloud cover on monthly images, are available on annual images (where missing distal pixels represent only $1 \%$ of the total surface).

\subsection{Surface area as a function of incident light}

Let us define the cumulative function $P$ : given an irradiance level on the sea floor $E_{z}, P$ is the percentage of the surface of the coastal zone receiving an irradiance greater than $E_{z}$ (in mol photons $\mathrm{m}^{-2} \mathrm{~d}^{-1}$ ). This percentage was calculated for each of the monthly and annual images. The average annual function ( $P_{a}$, the mean of the annual functions) was calculated, as well as the average monthly $P$-function for each month (12 for the non-polar region and 5 for the Arctic region, as explained in Sect. 3.1). For example, $P_{\text {june }}$ is the mean of the $P$-functions calculated for all June images between 1998 and 2003. Finally, the $P_{m}$ function was constructed as the mean of the monthly $P$-functions. In the Arctic region, the $P_{a}$ and $P_{m}$ functions are different because annual images in this region, where data are not available during 7 months, are strongly biased. In the non-polar region, the $P_{a}$ and $P_{m}$ functions provide similar percent surface areas (a relative error of less than $10 \%$ between the minimum 

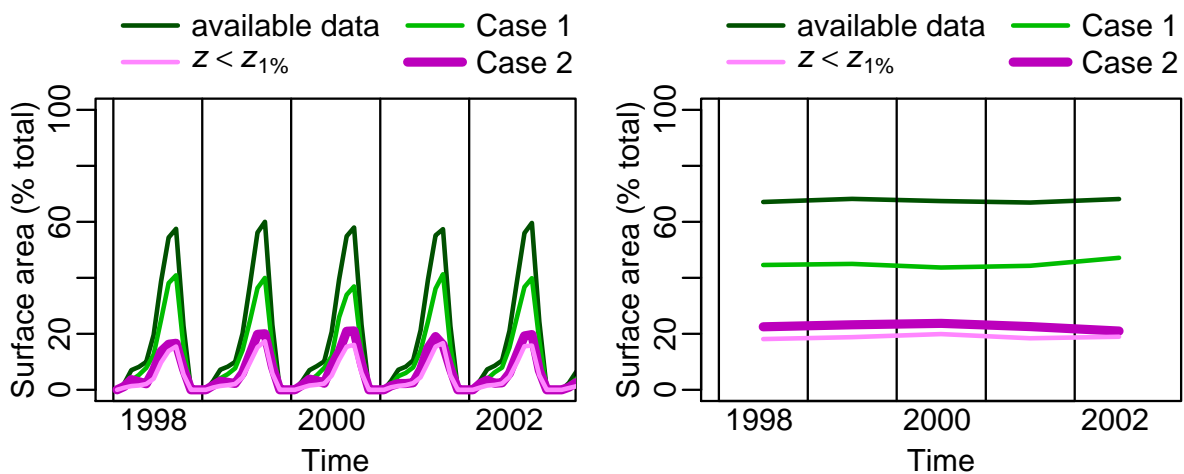

A: Arctic
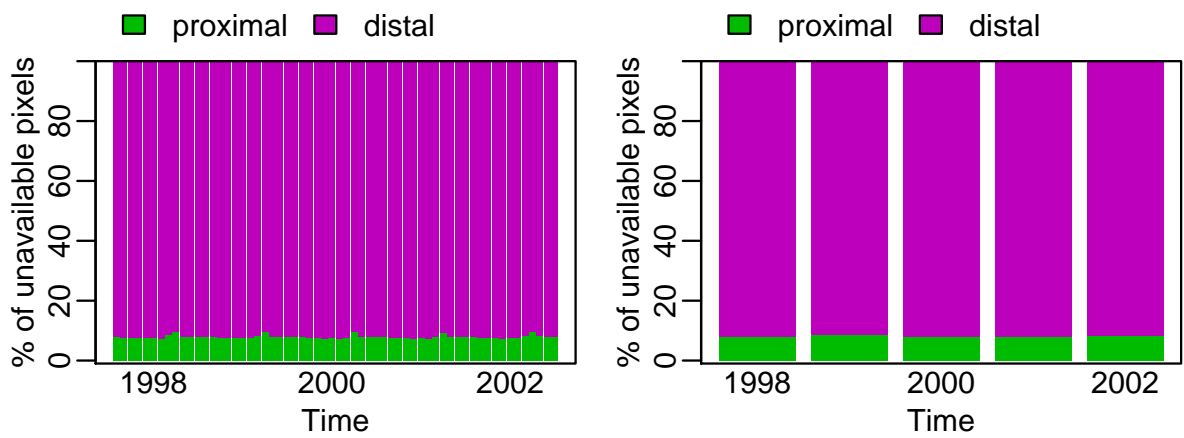

Fig. 3. Monthly and annual changes in the surface area of the SeaWiFS pixels available (i.e. for which $C_{\text {sat }}, n L w(555)$ and PAR are available for analysis), Case 1 and Case 2 pixels, and of the geographical zone where irradiance is higher than $1 \%$ of surface irradiance $\left(Z_{1 \%}\right)$ in the Arctic and non-polar regions. The percent contribution of the proximal and distal pixels to the total number of pixels not available is also shown. Proximal coastal pixels are defined as pixels comprising a portion of the coastline; all other coastal pixels are defined as distal.

and maximum values, and a relative error of less than $4 \%$ between $P_{a}$ and $P_{m}$ for $E_{z}<10 \mathrm{~mol}$ photons $\mathrm{m}^{-2} \mathrm{~d}^{-1}$ ). $P_{m}$ is therefore used for the rest of this study. Figure 4 shows the $P_{m}$ functions. The surface area receiving a certain irradiance threshold is larger for Case 2 than for Case 1 waters because the former are shallower than the later (e.g. $52 \mathrm{vs} .83 \mathrm{~m}$ in the non-polar region; Table 1).

\section{Discussion}

Coastal and offshore waters have been classified into several types according to their optical characteristics (e.g., Jerlov, 1977; Morel and Prieur, 1977; Pelevin and Rutkovskaya, 1977). Several local and regional distributions of these water types are available but their large scale geographical distributions are unknown. This study is the first attempt to describe the distribution of two water types in the coastal ocean, with optical characteristics dominated (Case 2) or not (Case 1) by allochthonous CDOM and suspended solids. In this section, the validity of the assumptions involved in the method used and the resulting uncertainties are analyzed. The geographical distributions of Case 1 and Case 2 waters are then discussed, the irradiance reaching the bottom of the coastal ocean estimated, and, together with the light requirement of the major benthic primary producers, is used to estimate the surface area of the coastal ocean where benthic primary production can proceed. These areas are broken down as polar vs. non-polar, and Case 1 vs. Case 2.

4.1 Distribution of benthic irradiance and assumptions involved

Pixels not available for analysis have three origins: (1) data acquisition was not performed because the area was not covered by SeaWiFS (high latitude), (2) data were collected but subsequently eliminated either due to high reflectance from adjacent land or to high turbidity, and (3) cloud cover prevented acquisition of useful data. These three sources vary, some of them considerably, with season. This is consistent with many observations that specific geographical locations on the continental shelf belong to different optical water types depending on the season (Højerslev and Aarup, 2002). However, only $12 \%$ of the surface area of the coastal ocean is missing on annual images and it is mostly represented by distal pixels (with an average depth of $73 \mathrm{~m}$ ), most of which probably do not experience light penetration to the bottom. Only 3\% of the missing proximal pixels (average depth of $22 \mathrm{~m}$ ) can potentially receive irradiance at the bottom. Another possible drawback of using annual images is that some 

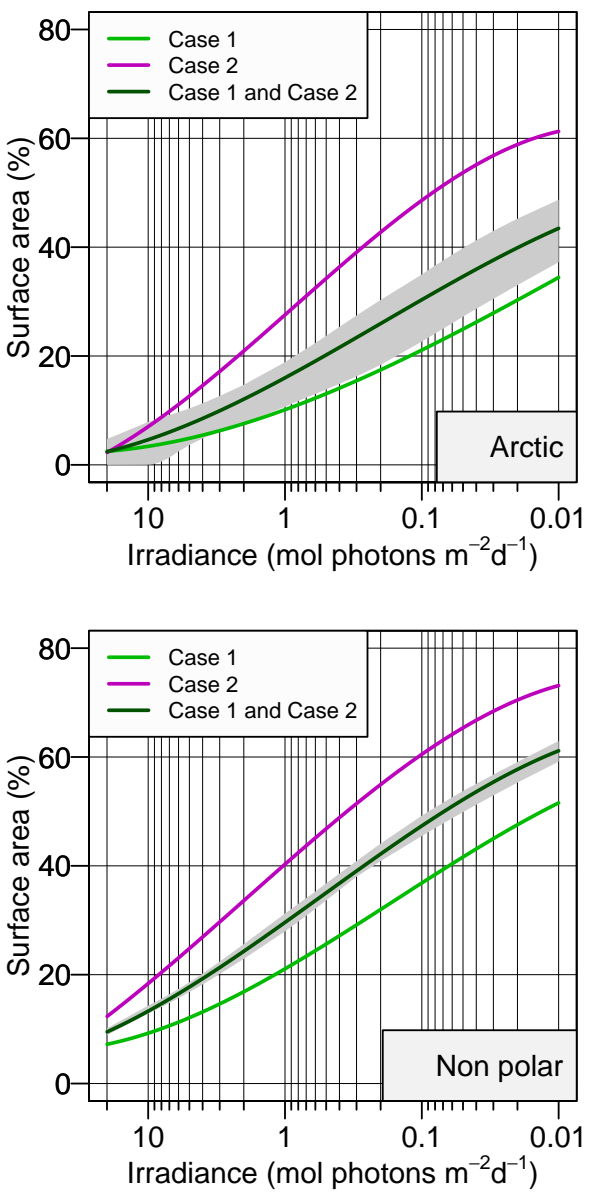

Fig. 4. Cumulative surface area of the sea floor $(S)$ receiving irradiance above a prescribed threshold $\left(E_{z}\right)$. Data are expressed in percent of the surface area for which information is available (6126726 and $18821140 \mathrm{~km}^{2}$, respectively for the Arctic and non-polar regions). For example, in the non-polar region, about $20 \%$ of the surface area overlain by Case 1 waters receives at least $1 \mathrm{~mol} \mathrm{photons} \mathrm{m}^{-2} \mathrm{~d}^{-1}$. The shaded zone depicts the range all monthly $P$-functions for case 1 and case 2 waters. The solid lines correspond to the annual functions calculated as the average of the monthly functions $\left(P_{m}\right)$. Note that data for the Arctic are based on the five months of the year when light levels were within the detection limits of the SeaWiFS sensor; i.e., only summer months were included (see Sect. 3.1). For this region, to convert the daily irradiance value (mol photons $\mathrm{m}^{-2} \mathrm{~d}^{-1}$ ) to an annual irradiance value (mol photons $\mathrm{m}^{-2} \mathrm{y}^{-1}$ ), one must multiply the daily value by $(5 / 12) \times 365 \mathrm{dy}^{-1}$. The polynomial equations of the lines shown are:

Arctic Case 1: $S=10.13-9.15 \log _{10}\left(E_{z}\right)+2.12 \log _{10}^{2}\left(E_{z}\right)+0.31 \log _{10}^{3}\left(E_{z}\right)$;

Arctic Case 2: $S=27.56-22.26 \log _{10}\left(E_{z}\right)+0.25 \log _{10}^{2}\left(E_{z}\right)+1.48 \log _{10}^{3}\left(E_{z}\right)$;

Arctic Case 1 and Case 2: $S=15.99-13.56 \log _{10}\left(E_{z}\right)+1.49 \log _{10}^{2}\left(E_{z}\right)+0.70 \log _{10}^{3}\left(E_{z}\right)$;

non-polar Case 1: $S=21.07-14.64 \log _{10}\left(E_{z}\right)+1.97 \log _{10}^{2}\left(E_{z}\right)+0.83 \log _{10}^{3}\left(E_{z}\right)$;

non-polar Case 2: $S=40.29-22.03 \log _{10}\left(E_{z}\right)-0.86 \log _{10}^{2}\left(E_{z}\right)+0.97 \log _{10}^{3}\left(E_{z}\right)$;

non-polar Case 1 and Case 2: $S=29.61-17.92 \log _{10}\left(E_{z}\right)+0.72 \log _{10}^{2}\left(E_{z}\right)+0.90 \log _{10}^{3}\left(E_{z}\right)$.

areas have only been sampled a few times over the period of one year. This introduces a bias in areas where light penetration varies with season, particularly in high-latitude environments. In the Arctic, for example, light levels could only be calculated for the five summer months, and we calculated the annual average light penetration based only on those five months. This provides a more realistic value of light at the surface and its depth of penetration (including the dark winter months would have grossly underestimated the percent surface area that can support photosynthesis), but the limitation must be taken into account when extrapolating the data to a full year (that is, significant photosynthesis only occurs on the Arctic shelf for five months). Parameters other than day length change seasonally, such as river discharge, wave height and resulting sediment resuspension, and water column stratification (R. Jahnke, personal communication).

The overall comparison of the SeaWiFS chlorophyll data with field measurements is quite remarkable with an $r^{2}$ of 
0.76 (Gregg and Casey, 2004). When data are split into open ocean and coastal waters (using the $200 \mathrm{~m}$ depth contour), the correlation is significantly lower in the coastal ocean than in the open ocean $\left(r^{2}\right.$ of 0.60 vs. 0.72$)$. According to Gregg and Casey (2004), there are more than ten impediments to retrieval of accurate water column chlorophyll from ocean color remote sensing. Among them, the presence of allochthonous chromophoric dissolved organic matter (CDOM) and suspended sediments mostly apply to coastal waters. The regional analyses that they carried out show that the standard SeaWiFS algorithm overestimates the chlorophyll concentration in coastal region. We have estimated that $38 \%$ of the ratios SeaWiFS:in situ chlorophyll are below 1 while $62 \%$ are above 1 . In addition the the watercolumn impediments listed by Gregg and Casey (2004), sediment resuspension near the sea floor can greatly reduce benthic irradiance (R. Jahnke, personal communication). It was not taken into account in the present study but more benthic irradiance data would be needed to assess its importance on a global scale.

The nearly global scope of the present analysis does not capture the large spatial and temporal variability of the light field in the coastal ocean. For example, changes in the optical properties of the water column occur within scales of a few $100 \mathrm{~m}$ and daily irradiance can change by up to one order of magnitude or more in a coastal turbid environment. Anthony et al. (2004) identified four key factors which affect temporal changes of irradiance: (1) the seasonal pattern of daily surface irradiance, (2) cloudiness, (3) light transmission in the water column which depends on turbidity and (4) tides.

According to the criteria used, more than half $(55 \%)$ of the coastal ocean has optical characteristics of Case 1 waters (Table 2), and are hence relatively unaffected by allochthonous CDOM and suspended solids. Another unexpected outcome of this study is that Case 2 waters are not preferentially distributed close to shore. A large fraction (43\%) of areas distant from shore are affected by allochthonous CDOM and suspended solids, probably corresponding to river plumes and relatively shallow areas influenced by sediment resuspension or upwelling.

The euphotic zone typically exhibits an excess of gross primary production over community respiration, hence net community production is positive. Its lower limit is often arbitrarily set at $1 \%$ of surface irradiance. According to our analysis (Table 1), 25 and 37\% of the Arctic and non-polar coastal zone receive more than this level (34\% for these two regions combined). Nelson et al. (1999) reported that bottom irradiance is often 4 to $8 \%$ of surface irradiance over much of the South Atlantic Bight, and exceeds $10 \%$ of surface irradiance on occasion. Jahnke et al. (2000) estimated that the area-weighted annual average light flux to the sea floor of the Southeastern US continental shelf is $5.4 \%$ of the surface irradiance (or $1.8 \mathrm{~mol}$ photons $\mathrm{m}^{-2} \mathrm{~d}^{-1}$ ).

Expressing light requirements for benthic primary production in percent of surface irradiance, however, is biologically meaningless (Lüning and Dring, 1979). The distribution of photosynthetic organisms and the metabolic performances of photosynthetic communities are controlled by absolute irradiance levels, or compensation irradiance (see below). Percent of surface irradiance does not translate into absolute irradiance because the surface irradiance itself varies considerably with latitude and cloud cover (e.g., Klöser et al., 1993). Banse (2004) recently advocated the use of absolute rather than percent of incident irradiance for phytoplankton communities, pointing out that the $1 \%$-depth for moonlight is about the same as the 1\%-depth for sunlight. The analysis that follows is therefore based on absolute rather than relative irradiance.

\subsection{Distribution of major primary producers and net ecosystem metabolism}

In this section, we compile data on the constraint of light availability on the major benthic primary producers and on net community production. Then, the data are combined with the irradiance data derived in Sect. 3.1 to produce estimates of the surface area where (1) light does not limit the distribution of primary producers and (2) net community production (the balance between gross primary production and community respiration) is positive.

\subsubsection{Metrics of light requirements}

Benthic primary producers, including prokaryotes, plants, and animals living in symbiosis with algae (e.g., zooxanthellate corals), rely on irradiance to proceed with photosynthesis. The dependence of benthic primary production on irradiance can be defined by three distinct compensation irradiances:

- Compensation irradiance for photosynthesis $\left(E_{c}\right.$ phot. $)$ : This is the irradiance at which net photosynthesis is 0 (the rates of gross photosynthesis and autotrophic respiration are equal). Instantaneous $E_{c \text { phot. is typically }}$ inferred from experimental photosynthesis-irradiance curves in laboratory of field incubations over time spans of less than $24 \mathrm{~h}$, sometimes over seconds. The daily $E_{c}$ phot. is defined for a period of $24 \mathrm{~h}$ and is the daily irradiance below which daily net photosynthesis is 0 . It is not often reported in the literature.

- Compensation irradiance for growth $\left(E_{c}\right.$ growth; sensu Markager and Sand-Jensen, 1994): This is the irradiance at which gross primary production balances the carbon losses (respiration, herbivory, exudation of dissolved organic carbon, and reproduction) for a partic-

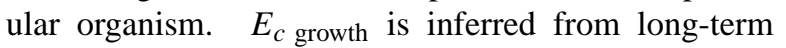
growth-irradiance experiments (Markager and SandJensen, 1994) or, empirically as the irradiance at the depth limit of the distribution of benthic primary producers (e.g. Appendix 1 in Duarte, 1991). For benthic 


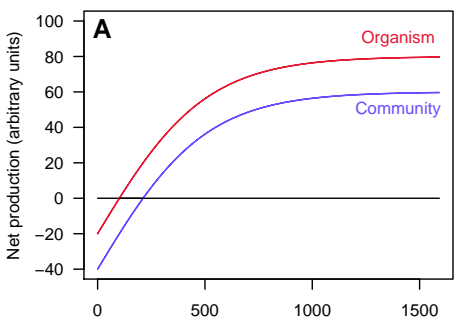

Instantaneous benthic irradiance $\left(\mu \mathrm{mol} \mathrm{m} \mathrm{m}^{-2} \mathrm{~s}^{-1}\right)$
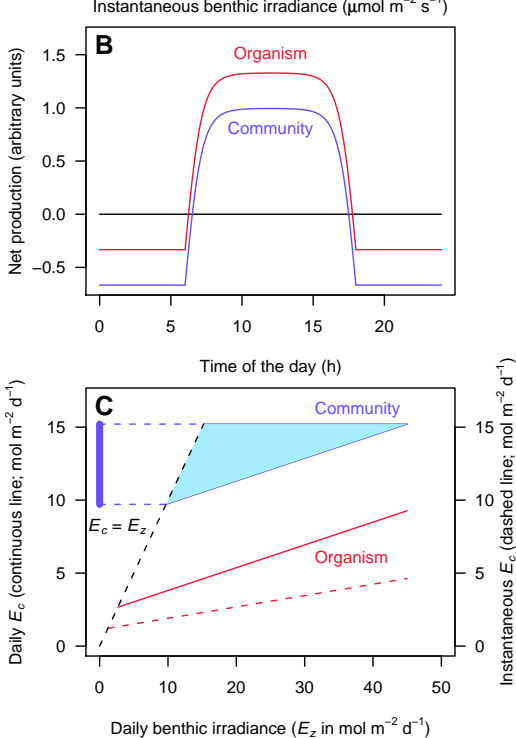

Fig. 5. Arbitrary $P-E$ curve (A), diel change of net primary (insets) and community production (B) and changes in daily $E_{c}$ as a function of daily irradiance $(\mathbf{C})$ for photosynthetic organisms and communities. The primary production of an organism was calculated using the hyperbolic tangent function $n p p=g p p_{\max } \times \tanh \left(E_{z} / E_{k}\right)+r_{a}$ where: $n p p$ is the rate of net primary production, $g p p_{\max }$ is the maximum rate of gross primary production (set at 100), $E_{z}$ is the benthic irradiance, $E_{k}$ is the irradiance at which the initial slope of the $P-E$ curve intersects the horizontal asymptote (set at $50 \mu \mathrm{mol}$ photons $\mathrm{m}^{-2} \mathrm{~s}^{-1}$ ) and $r_{a}$ is the rate of dark respiration of the autotrophs (set at -20 ). $E_{z}$ and $E_{k}$ are in $\mu \mathrm{mol}$ photons $\mathrm{m}^{-2} \mathrm{~s}^{-1}$. The diel change in irradiance was modeled using a sine curve and using a photoperiod of $12 \mathrm{~h}$ dark and $12 \mathrm{~h}$ light. The rate of net community production was calculated assuming that the rates of dark respiration of the heterotrophs and autotrophs are equal. $r_{a}$ was therefore simply added to the $n p p$ of the organism. In this generic example, the instan-

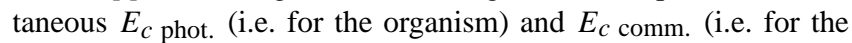
community) are, respectively, 101 and $212 \mu \mathrm{mol}$ photons $\mathrm{m}^{-2} \mathrm{~s}^{-1}$ (panels A and B). In panel (C), daily $E_{c}$ (continuous lines) is twice the instantaneous $E_{c}$ (dashed line) and the shaded area indicates the range of daily $E_{c}$ for communities. This area is enclosed within an upper line which assumes no photoacclimation and a lower line which assumes a photoacclimation parallel to the one reported for individual organisms. The thick blue line shows the range of daily compensation irradiance. Irradiance in $\mu \mathrm{mol}$ photons $\mathrm{m}^{-2} \mathrm{~d}^{-1}$ is calculated using the relationship $0.0432 \times$ irradiance (in $\mu \mathrm{mol}$ photons $\mathrm{m}^{-2} \mathrm{~s}^{-1}$ ) assuming a photoperiod of $12 \mathrm{~h}$ dark and $12 \mathrm{~h}$ light. organisms, $E_{c}$ growth also integrates the light requirements over long periods of time, effectively smoothing out seasonal changes in irradiance. Here one assumes that light attenuation with depth is the only factor limiting the vertical distribution, although other factors limit the colonization depths of benthic primary producers (e.g., terracing, thermocline, competition, etc.).

- Compensation irradiance for community metabolism $\left(E_{c}\right.$ comm. $)$ : This is the irradiance at which gross community primary production $(G P P)$ balances respiratory carbon losses $(R)$ for the entire community. Instantaneous $E_{c \text { comm. }}$ is typically inferred from experimental photosynthesis-irradiance curves over time spans of less

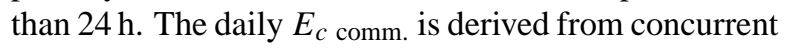
measurements of daily irradiance and daily net community production $(N C P)$ at different depths. The use of shading experiments on communities at a single depth (e.g. Gacia et al., 2005) are useful in investigations of short-term (a few weeks) photoacclimation but do not provide useful information on metabolic performances as a function of depth because they do not account for depth-related changes in the community composition. Additionally, such experiments must be relatively long (up to a few months) in order to ascertain that the community is acclimated to the new light field.

These three compensation irradiances have different meaning, availability, and usefulness in the context of this paper. $E_{c}$ phot. is by far the most often reported measure of compensation irradiance while $E_{c \text { comm. }}$ is the least often measured, being limited to a few experiments carried out mostly on shallow water communities. $E_{c}$ phot. is an important physiological trait, but does not have a direct translation into the distribution and long-term production of benthic organisms. It approximates $E_{c}$ growth only when measurements are obtained from individuals collected close to the depth limit of a particular species or acclimated at an irradiance close to that found at the depth limit (Markager and Sand-Jensen, 1992). These conditions are not frequently met. $E_{c}$ growth, for which there is a reasonable empirical basis, is the relevant parameter for estimating the areal extent of benthic primary producers (the area receiving irradiances $\geq E_{c}$ growth). Benthic communities growing at irradiances close to $E_{c}$ growth are unlikely to exhibit a positive $N C P$. This is because $R$, which is often sizeable relative to GPP, should exceed $G P P$ at $E_{c \text { growth }}$, rendering deep photosynthesizing communities heterotrophic with respect to carbon (i.e., dependent on inputs of organic carbon from adjacent systems). $E_{c}$ comm. represents the threshold irradiance above which benthic communities are autotrophic and can contribute to net production of organic carbon in coastal ecosystems. Note that net primary production of the autotrophs can be significant below this threshold, even though the community is heterotrophic.

We will focus on $E_{c \text { growth }}$ and $E_{c \text { comm. as the }}$ ecologically- and biogeochemically-relevant irradiance 
thresholds for benthic communities. These thresholds respectively delineate the deepest extent of benthic primary producers and the depth over which benthic communities act as net sources of organic carbon to coastal ecosystems. Figure 5 illustrates the relationship between $E_{c \text { phot. and }}$ $E_{c \text { comm. }}$ and their changes with irradiance. Three important observations are apparent in this figure. First, instantaneous $E_{c \text { comm. }}$ should be higher than instantaneous $E_{c \text { phot. }}$ (Figs. 5a and c). It should also occur later in the morning and earlier in the afternoon (Fig. 5b) because communities include heterotrophs as well as autotrophs, which increases respiration relative to primary production and thus raises the compensation irradiance. Second, instantaneous $E_{c}$ phot. of organisms generally decreases with decreasing benthic irradiance due to photoacclimation: low-light adapted specimens therefore have less light requirements than high-light adapted specimens (Fig. 5c). Third, the slope of the relationship $E_{c}$ versus $E_{z}$ is lower for communities than for organisms because the ratio of autotrophs to heterotrophs decreases with decreasing irradiance.

For ecosystems such as coral reefs, the precise photoacclimation function is unknown because $E_{c}$ comm. data are reported as instantaneous values obtained on shallow-water communities whereas, as outlined above, daily values at depths are required to estimate the surface area of the coastal ocean which receives enough light to contribute to net primary production. The photoacclimation function can be bracketed by an upper bound which assumes no photoacclimation and a lower bound which assumes that photoacclimation of communities is similar to that observed in the main photosynthetic organism of the community. The true function lies in the light blue area shown in Fig. 5c).

\subsubsection{Review of the light requirements of benthic primary producers}

The maximum depth of distribution of primary producers, which represents an estimate of $E_{c}$ growth, ranges from 90 to $285 \mathrm{~m}$ corresponding to 11 to $0.0005 \%$ of incident surface irradiance (Table 3). These depths demonstrate the outstanding photoadaptative capabilities of some primary producers but are not very useful for estimating their global depth distribution. Logically, benthic primary producers occur most deeply in exceptionally clear waters, in accordance with the negative relationship between the depth limit and water transparency (e.g. Duarte, 1991, for seagrasses). Moreover, benthic primary producers occur in very low abundance at these depths, where their contribution to primary production is negligible. The light requirements of the major benthic primary producers are reviewed below, but we first address the special case of organisms living in polar regions.

\section{Special consideration for polar regions}

Polar regions are the most difficult to address due to scant information on benthic irradiance along the Antarctic coast (see Sect. 3), vertical distribution of primary producers, and acclimation processes other than photoacclimation. Estimating light penetration on a large spatial scale is difficult at high latitudes because of the poor coverage by SeaWiFS (Sect. 4.1) and the considerable seasonal change in light absorption by ice and snow covers, and sub-ice platelets. However, there are local estimates of light penetration. For example, Robinson et al. (1995) reported that approximately $0.05 \%$ of the irradiance incident on the sea ice (about $2 \mathrm{~m}$ thick) surface at noon or 0.2 to $0.6 \mu \mathrm{mol}$ photons $\mathrm{m}^{-2} \mathrm{~s}^{-1}$ reaches the sea floor at $23 \mathrm{~m}$ depth in McMurdo Sound, Antarctica. Borum et al. (2002) provided estimates of the cumulated annual benthic irradiance in a high-arctic fjord of NE Greenland covered by ice for about 10 months a year: 234, 96 and $40 \mathrm{~mol}$ photons $\mathrm{m}^{-2}$ year ${ }^{-1}$ at 10,15 and $20 \mathrm{~m}$ depth, respectively. Schwarz et al. (2003) estimated that annual irradiance at Cape Evans $\left(77^{\circ} 38^{\prime} \mathrm{S}\right)$ ranges from 111.6 to 17.7 mol photons $\mathrm{m}^{-2}$ year $^{-1}$, respectively at 10 and $30 \mathrm{~m}$ depth. It must also be noted that coastal waters can be clear

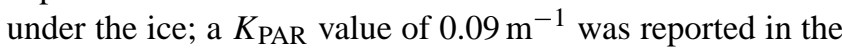
Ross Sea (Schwarz et al., 2003).

The cumulated annual irradiance at depth probably controls the depth distribution of photosynthetic organisms. The seasonal depth of light penetration exhibits dramatic seasonal changes at high latitudes: the total insolation in summer may actually exceed that of lower latitudes (because of longer day length) but, due to higher zenith angles, more of the light is reflected off the surface rather than penetrating the air-sea interface. Some organisms may require some daily minimum irradiance to survive; that is, their bottom limit of distribution is limited by winter time irradiance. Others are known to suspend growth during winter darkness, aided by the reduced carbon expenditure as reflected in lower rates of respiration in colder waters. At $20 \mathrm{~m}$, the depth limit for the alga Laminaria saccharina in an Arctic Greenland fjord, annual irradiance is $40 \mathrm{~mol}$ photons $\mathrm{m}^{-2}$ or about $0.7 \%$ of surface irradiance (Borum et al., 2002). The net carbon balance is negative during most of the ice covered period but the summer primary production is large enough to maintain a positive annual carbon balance $(G P P / R=1.2)$. Despite extended periods of extreme light limitation, and because of strong photoacclimation processes, the light requirement at this site is only slightly lower than that of other cold-water laminariales (e.g., Lüning and Dring, 1979). This suggests that light limitation for this group of macroalgae, and possibly others, should therefore be considered on an yearly basis.

Saprotrophy, the ability to assimilate dissolved organic substrates, is another acclimation process that can support normally photosynthetic organisms during periods of low irradiance. Antarctic benthic diatoms, for example, can be saprotrophic. This ability could also support heterotrophic 
Table 3. Deepest known benthic primary producers. Note that data for microalgae may be the result of downslope transport, although this possibility was ruled out by Cahoon (1986).

\begin{tabular}{lcccc}
\hline & Seagrasses & Macroalgae & Microalgae & Corals \\
\hline Reference & Den Hartog (1970) & Littler et al. (1985) & Cahoon (1986) & Maragos and Jokiel (1986) \\
Deepest record $(\mathrm{m})$ & 90 & 268 & 285 & 165 \\
$\%$ surface irradiance & 11 & 0.0005 & 0.1 & 0.02 \\
$E_{c \text { growth }\left(\text { mol photons } \mathrm{m}^{-2} \mathrm{~d}^{-1}\right)}$ & 5 & 0.0002 & 0.04 & 0.009 (a) \\
\hline
\end{tabular}

(a) $K_{\mathrm{PAR}}$ from Agegian and Abbott (1985)

growth of microphythobenthic algae during the aphotic polar winter (Rivkin and Putt, 1988).

The depth limits of Antarctic macroalgae have been compiled by Klöser et al. (1993). Benthic photosynthesis occurs despite very low light levels due to periods of darkness of up to four months, and cloud, ice and snow covers. Coralline algae have low light requirements, can sustain prolonged periods of darkness, and seem to be well distributed at high latitudes (Schwarz et al., 2003). Brown algae have light requirements as low as $31 \mathrm{~mol}$ photons $\mathrm{m}^{-2}$ year $^{-1}$ (Wiencke, 1990, in Schwarz et al., 2003).

Surface area potentially available for benthic primary producers

Here we combine estimates of the irradiance reaching the bottom of the coastal ocean derived in Sect. 3.3 with estimates of $E_{c}$ growth to provide the maximum extent of the area of distribution of different benthic organisms. The limitations related to the use of SeaWiFS data to estimate the irradiance reaching the sea floor are described in Sect. 4.1. There are also biological and sedimentological sources of uncertainty. The method of estimating benthic irradiance assumes that there is no shading from other erect organisms nor epibionts. The effects of backscaterring within the sediment, which can result in a 50\% increase of the light exposure of some microphytobenthic communities (Kühl and Jørgensen, 1992), are also neglected. Finally, tidal effects were ignored, which in areas subject to large tidal amplitude, can induce hourly, daily and seasonal variations in light penetration by altering the height of the water column and turbidity (e.g., Dring and Lüning, 1994). Data on both the maximum depth of occurrence of species and the irradiance at this depth were compiled from the literature to determine the surface area where benthic primary producers are not light limited. Often the benthic irradiance was not reported but either the attenuation coefficient or the percent light penetration was (sometimes in another paper); in this case, the benthic irradiance was estimated by combining this value with the surface PAR value from SeaWiFS.

\section{Bacteria and Archaea}

Photosynthetic Bacteria and Archaea are very diverse, both taxonomically and functionally as they utilize the three known types of photosynthesis (Karl, 2002). Oxygenic photosynthesis generates oxygen as a by-product whereas aerobic anoxygenic and anaerobic anoxygenic photosynthesis do not. Their importance is likely minor in terms of global benthic primary production. The very poor knowledge on the depth distribution and light requirements of Bacteria and Archaea prevents any attempt to delineate the extent of their geographic distribution. It is, however, worth noting that some of them have developed extremely efficient mechanisms to acclimatize to light levels as low as $0.0005 \%$ of surface irradiance (or $0.003 \mu \mathrm{mol}$ photons $\mathrm{m}^{-2} \mathrm{~s}^{-1}$; Overmann et al., 1992).

\section{Seagrasses}

Seagrasses are flowering plants that grow on various soft substrata along the shores of all continents, except Antarctica, up to $75^{\circ} \mathrm{N}$. They colonize areas with suitable sediments down to $10.8 \%$ of surface irradiance (Duarte, 1991) and the deepest depth of colonization is $90 \mathrm{~m}$ in the Dry Tortugas (Table 3; Den Hartog, 1970). Duarte (1991) reviewed literature data on seagrass depth distribution and light attenuation and derived the following relationship between the maximum colonization depth $\left(Z_{c}\right.$, in $\left.\mathrm{m}\right)$ and the light attenuation coefficient $\left(K_{\mathrm{PAR}}\right.$, in $\left.\mathrm{m}^{-1}\right)$ :

$$
L N\left(Z_{c}\right)=0.26-1.07 \times L N\left(K_{\mathrm{PAR}}\right)
$$

A few additional data were added to Duarte's compilation. The data on Zostera marina produced by Nielsen et al. (2002) were not used because the geographical location of the stations was not provided. However, the distribution of this species in Danish waters is very well covered in our data set (available in Appendix C) from the 20 stations reported by Nielsen et al. (1989). The maximum depth of distribution of seagrasses ranges from 0.7 to $50 \mathrm{~m}$, with a median value of $4.4 \mathrm{~m}$. The minimum light requirement varies widely across species (range of median: 0.06 to 14.1 mol photons $\mathrm{m}^{-2} \mathrm{~d}^{-1}$; Table 4). The overall median of the minimum light requirement is 5.1 mol photons $\mathrm{m}^{-2} \mathrm{~d}^{-1}$. About $19 \%$ and $38 \%$ of 
Table 4. Minimum light requirements (mol photons $\mathrm{m}^{-2} \mathrm{~d}^{-1}$ ) of seagrasses. The complete data set is available in Appendix C.

\begin{tabular}{lcccc}
\hline Species & Number of data & Range & Mean & Median \\
\hline Cymodocea nodosa & 2 & $0.1-0.1$ & 0.1 & 0.1 \\
Halophila decipiens & 1 & - & 3.8 & 3.8 \\
Halophila engelmannii & 1 & - & 10.2 & 10.2 \\
Halophila stipulacea & 1 & - & 0.2 & 0.2 \\
Heterozostera tasmanica & 9 & $0.7-8.2$ & 2.9 & 1.7 \\
Posidonia angustifolia & 2 & $2.4-10.1$ & 6.2 & 6.2 \\
Posidonia coriacea & 1 & - & 3.2 & 3.2 \\
Posidonia oceanica & 2 & $0.1-2.8$ & 1.4 & 1.4 \\
Posidonia ostenfeldii & 1 & - & 10.1 & 10.1 \\
Posidonia sinuosa & 1 & - & 10.1 & 10.1 \\
Ruppia sp. & 1 & - & 3.3 & 3.3 \\
Syringodium filiforme & 3 & $0.2-8.3$ & 5.3 & 7.5 \\
Thalassia testudinum & 15 & $0.2-14.1$ & 8.6 & 8.5 \\
Thalassodendron ciliatum & 3 & $1-4.4$ & 2.2 & 1.3 \\
Zostera marina & 45 & $1.2-12.6$ & 6.0 & 5.4 \\
All & 88 & $0.06-14.1$ & 5.8 & 5.1 \\
\hline
\end{tabular}

Table 5. Percent surface area where irradiance does not limit the distribution of photosynthetic organisms. Data are expressed relative to the surface area for which information is available: 18821140 and $6126726 \mathrm{~km}^{2}$, respectively for the non-polar and Arctic regions. Data are not reported in the Arctic region for seagrasses nor for reef corals where these groups are not present.

\begin{tabular}{lcccccc}
\hline & \multicolumn{3}{c}{ Non-polar region } & \multicolumn{2}{c}{ Arctic region } \\
Organism & Case 1 & Case 2 & Cases 1 and 2 & Case 1 & Case 2 & Cases 1 and 2 \\
\hline Seagrasses & 19 & 38 & 28 & - & - & - \\
Macroalgae & & & & & & \\
- Filamentous and slightly corticated filamentous & 32 & 55 & 42 & 17 & 43 & 26 \\
- Corticated foliose, corticated and foliose & 37 & 61 & 47 & 21 & 49 & 30 \\
- Leathery and articulated calcareous & 43 & 67 & 54 & 26 & 55 & 36 \\
- Crustose & 60 & 72 & 66 & 48 & 57 & 51 \\
Microphytobenthos & 27 & 49 & 37 & 14 & 36 & 22 \\
Scleractinian corals & 33 & 56 & 43 & - & - & - \\
\hline
\end{tabular}

the surface area respectively covered by Case 1 and Case 2 waters in non-polar regions receive at least this irradiance level (Table 5). Globally, seagrasses are not light-limited in only $28 \%$ of the non-polar region $\left(5.19 \times 10^{6} \mathrm{~km}^{2}\right)$. This surface area is about 9 times larger than the estimated potential area covered by seagrasse of 0.5 to $0.6 \times 10^{6} \mathrm{~km}^{2}$ (Duarte and Chiscano, 1999; Green and Short, 2003), which were also based on considerations of the potential suitable habitat, and 35 times larger than the documented seagrass extension (about $0.15 \times 10^{6} \mathrm{~km}^{2}$; Green and Short, 2003). The estimate produced here represents an upper limit which needs be corrected for the area occupied by other benthic communities (coral reefs and macroalgae) and unsuitable substrate, such as rock or highly mobile sediments. Yet, it suggests that previous estimates of the seagrass extension in the coastal zone were too conservative and that the actual area may be much larger than hitherto believed.
Although the scope of the present paper is global, data on light penetration and requirements are useful at the regional scale too. A good case study is the distribution of seagrasses in Australia. It also provides an opportunity for validation purposes and to highlight that parameters other than irradiance also control the distribution of benthic organisms. The Commonwealth Scientific and Industrial Research Organisation (CSIRO) compiled data on the distribution of seagrasses along the Australian coastline in 1996 (http://www.marine.csiro.au/nddq/ndd_search.Browse Citation?txtSession=246). The potential distribution of seagrasses in this region, estimated as the area where the benthos receives more than 5.1 mol photons $\mathrm{m}^{-2} \mathrm{~d}^{-1}$, is much larger than the distribution estimated by CSIRO (Fig. 7). A large patch, also captured in the present study, is reported by CSIRO in the Torres Strait. The discrepancy is largest along the northern and northeastern coasts and can be explained 
Table 6. Minimum light requirements (mol photons $\mathrm{m}^{-2} \mathrm{~d}^{-1}$ ) of the major macroalgal functional groups defined by Steneck (1988) and Steneck and Dethier (1994). The complete data set is available in Appendix D.

\begin{tabular}{lcccccc}
\hline Functional group & Number of data & Range & Mean & 1st decile & \multicolumn{2}{c}{ Median } \\
\hline Filamentous (group 2) & 7 & $0.1082-2.63$ & 1.40 & 0.12 & 1.56 & 1.63 \\
Slightly corticated filamentous (group 2.5) & 5 & $0.9289-2.63$ & 1.95 & 1.18 & 2.03 & \\
Corticated foliose (group 3.5) & 29 & $0.0483-2.49$ & 0.87 & 0.11 & 0.88 & 0.85 \\
Corticated (group 4) & 29 & $0.0317-2.63$ & 0.93 & 0.1 & 0.81 & \\
Foliose (group 3) & 4 & $0.0842-0.25$ & 0.13 & 0.09 & 0.10 & 0.28 \\
Leathery (group 5) & 22 & $0.0277-1.53$ & 0.50 & 0.06 & 0.31 & \\
Articulated calcareous (group 6) & 16 & $0.011-2.92$ & 0.65 & 0.04 & 0.19 & \\
Crustose (group 7) & 28 & $0.0001-5.0$ & 0.42 & 0.001 & 0.02 & 0.01 \\
Undefined & 22 & $0.0019-4.42$ & 1.16 & 0.37 & 0.44 & 0.44 \\
All & 162 & $0.0001-5.0$ & 0.81 & 0.019 & 0.31 & - \\
\hline
\end{tabular}

by three reasons. First, several parameters beside irradiance limit the distribution of seagrasses (e.g., Short, 1987). For example, wind-driven physical disturbances limit the distribution of seagrasses along the central Queensland coast (Carruthers et al., 2002). Second, the spatial coverage of field surveys in such a large region is inevitably patchy, with the result that the real distribution is underestimated (Kirkman, 1997). For example, the northern Australian shore is an area for which virtually no information is available (Kirkman, 1997). Third, the benthic environment may be already occupied by other communities, such as coral reefs, a possibility that our approach cannot resolve. Hence, the disagreement betwen our estimates and those of CSIRO may reflect the difference between documented (i.e. CSIRO) and realised area, with our estimates which represent the upper limit of the extent of seagrasses.

\section{Macroalgae}

Macroalgae are plants which have a very broad latitudinal distribution, from $77.9^{\circ} \mathrm{S}$ (e.g., Miller and Pearse, 1991) to $82^{\circ} \mathrm{N}$ (Lund, 1951, in Borum et al., 2002), and grow on both hard- and soft-bottoms. Two mechanisms have been described to explain their depth distribution. The first hypothesis is that the depth distributions of the different groups of macroalgae are related to their light harvesting capabilities, which in turn are a function of the spectral composition of light and the composition of their photosynthetic pigments. For example, red algae generally live deeper than green and brown algae. This hypothesis is supported by observations from many locations throughout the world (e.g. Larkum et al., 1967; Spalding et al., 2003) but many exceptions have have also been described. For example, red algae are distributed throughout the vertical range of algae on the coast of Maine (Vadas and Steneck, 1988). Exceptions to this rule are due to the control of other factors, such as grazing pressure or morphological variation such as the thickness of the thallus (Vadas and Steneck, 1988). Markager and Sand-Jensen (1992) concluded that there is "an upper zone of mainly leathery algae with depth limits of about $0.5 \%$ SI, an intermediate zone of foliose and delicate algae with depth limits at about $0.1 \%$ SI, and a lower zone of encrusting algae extending down to about 0.01\% SI" (SI: surface irradiance). Crustose coralline algae are the deepest-occuring macroalgae found to date (see Table 3), and can also routinely survive long periods of low irradiance (e.g., up to 17 months under ice at maximum irradiances below $0.07 \%$ of surface irradiance; Schwarz et al., 2005).

The compilation of Markager and Sand-Jensen (1994) was updated using additional and recently published data (Appendix D). The review of the algal depth maxima of Vadas and Steneck (1988) is very thorough but could not be used because it does not provide, except for their own study site, information on the attenuation coefficient or percent light penetration. Only data pertaining to adults were compiled; juveniles sometimes have different light requirements than adults, and light can limit the growth and distribution of some species such as Macrocystis pyrifera (e.g., Dean and Jacobsen, 1984). The species were classified using the functional groups based of morphological attributes defined by Steneck and Dethier (1994). We are aware of concerns expressed with the use of groupings based on morphology (Padilla and Allen, 2000), but such groups have been shown to be meaningful in investigations of the effect of light on macrophytes (Markager and Sand-Jensen, 1994).

The maximum depth of macroalgal distribution ranges from 6.4 to $268 \mathrm{~m}$, with a median value of $55 \mathrm{~m}$. The minimum light requirement varies considerably $(0.0001$ to $5 \mathrm{~mol}$ 

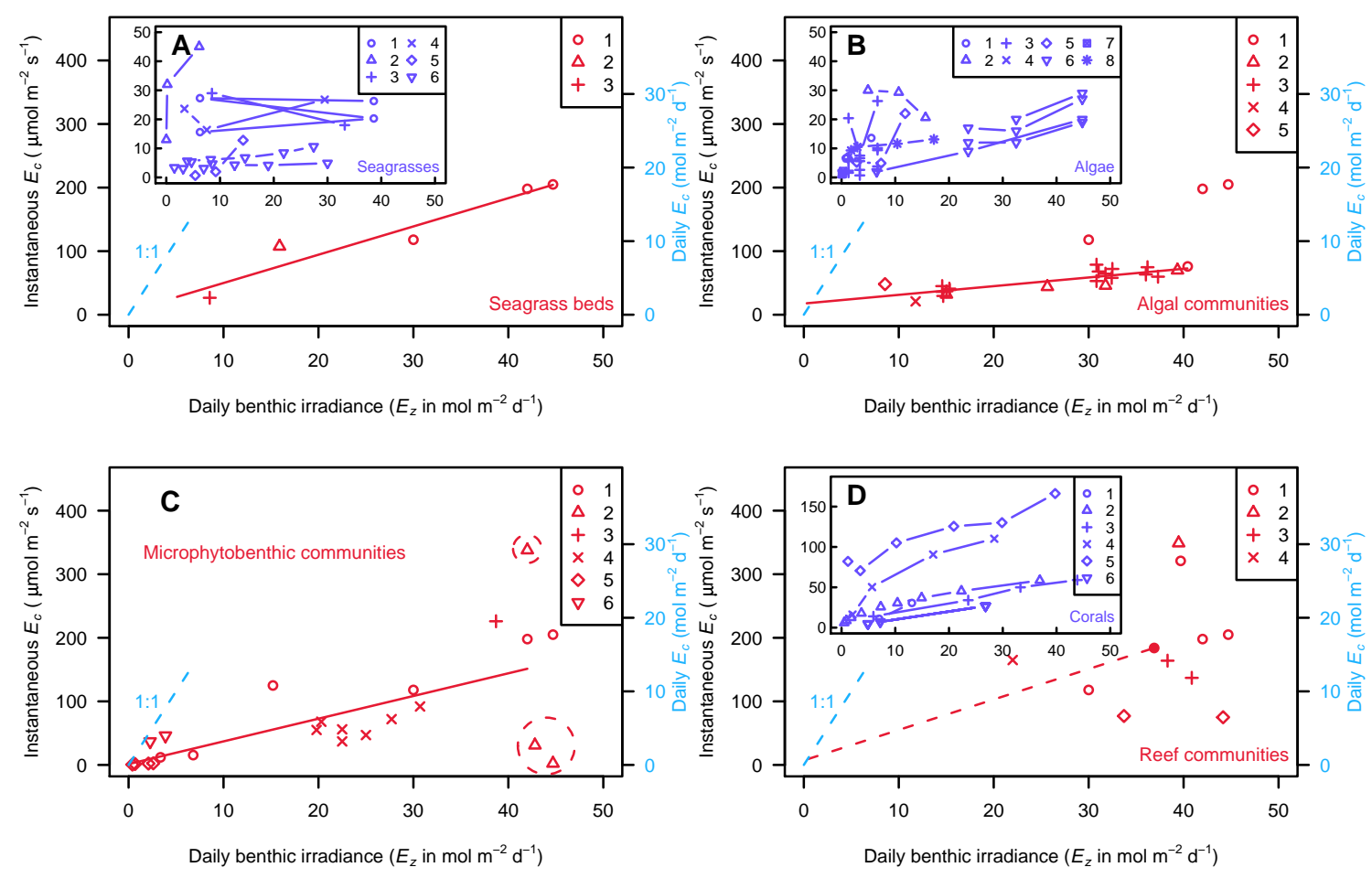

Fig. 6. Changes in instantaneous and daily $E_{c}$ as a function of daily irradiance for photosynthetic organisms and communities. A: seagrasses (symbols 1 to 6, respectively: Drew, 1978; Pirc, 1986; Dennison and Alberte, 1986; Titlyanov et al., 1995; Ruiz and Romero, 2001; Olesen et al., 2002) and seagrass communities (symbols 1 to 3, respectively: Erftemeijer et al., 1993; Herzka and Dunton, 1997; Martin et al., 2005). B: macroalgae (symbols 1 to 10, respectively: Gerard, 1988; Chisholm and Jaubert, 1997; Gómez et al., 1997; Roberts et al., 2002; Borum et al., 2002; Chisholm, 2003; Schwarz et al., 2003; Fairhead and Cheshire, 2004; Martin et al., 2005) and macroalgal communities (symbols 1 to 5, respectively: Carpenter, 1985; Klumpp and McKinnon, 1989, 1992; Cheshire et al., 1996). C: microphytobenthic communities (symbols 1 to 4, respectively: Herndl et al., 1989; Erftemeijer et al., 1993; Boucher et al., 1998; Uthicke and Klumpp, 1998; Glud et al., 2002). D: scleractinian corals and alcyonarians (symbols 1 to 5, respectively: Wethey and Porter, 1976; Chalker and Dunlap, 1983; Gattuso and Jaubert, 1985; Porter, 1985; Masuda et al., 1992; Fabricius and Klumpp, 1995) and coral reefs (symbols 1 to 5, respectively: Barnes and Devereux, 1984; Barnes, 1988; Gattuso et al., 1996; Hata et al., 2002; Kayanne et al., 2005). The data highlighted by dashed circles in panel (C) were omitted from the regression analysis. The complete data set is available in Appendix F.

photons $\mathrm{m}^{-2} \mathrm{~d}^{-1}$; Table 6). The median (the mean cannot be used because several groups exhibit a very skewed distribution) light limits of the functional groups range from $0.02 \mathrm{~mol}$ photons $\mathrm{m}^{-2} \mathrm{~d}^{-1}$ for crustose algae to $1.95 \mathrm{~mol}$ photons $\mathrm{m}^{-2} \mathrm{~d}^{-1}$ for slightly corticated filamentous algae. This is in agreement with the fact that the deepest known macrophyte is a crustose coralline alga (Littler et al., 1985). Overall, these light requirements are much lower than those reported for seagrasses. Only a few species of seagrasses (Cymodocea nodosa and Halophila stipulacea) have light requirements lower than most of the macroalgal functional groups (Tables 4 and 6). The functional groups were pooled into four categories according to their median light requirements (Table 6).

There is a relatively strong relationship $\left(r^{2}=0.70\right)$ between $K_{\mathrm{PAR}}$ and the maximum depth of occurrence of algae (Fig. 8), with similar a slope at low and high latitudes (data not shown). A similar relationship was reported for seagrasses by Duarte (1991, see above) but with a higher slope than in macroalgae (1.07 vs. 0.88). The maximum depth of occurrence therefore decreases less sharply as a function of the increase in light attenuation in macroalgae than in seagrasses, indicating that seagrasses are less tolerant to a decline in water transparency.

In the non-polar regions, about 32 to $60 \%$ and 55 to $72 \%$ of the surface areas respectively covered by Case 1 and Case 2 waters receive an irradiance level suitable for macroalgal colonization (Table 5). The large range is due to the wide range of light requirement of the various macroalgal groups. Globally, macroalgal distribution is not lightlimited in 42 to $66 \%$ of the non-polar region. About 26 to $51 \%$ of the Arctic coastal zone would receive enough light to harbor macroalgae. The potential extent of the geographical extension of macroalgae, calculated using the first decile of the minimum light requirements of the major functional groups $\left(0.0019 \mathrm{~mol}\right.$ photons $\mathrm{m}^{-2} \mathrm{~d}^{-1}$; Table 6), is 10.9 and $2.4 \times 10^{6} \mathrm{~km}^{2}$ in the non-polar and Arctic regions, respectively. These estimates, which do not take into account 
Potential seagrass distribution (SeaWIFS)

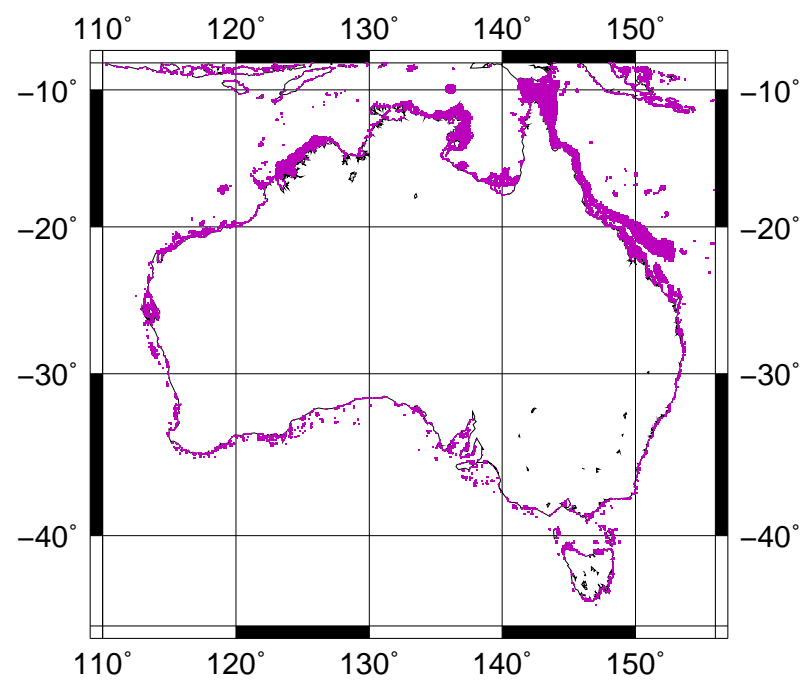

\section{Seagrass distribution (CSIRO)}

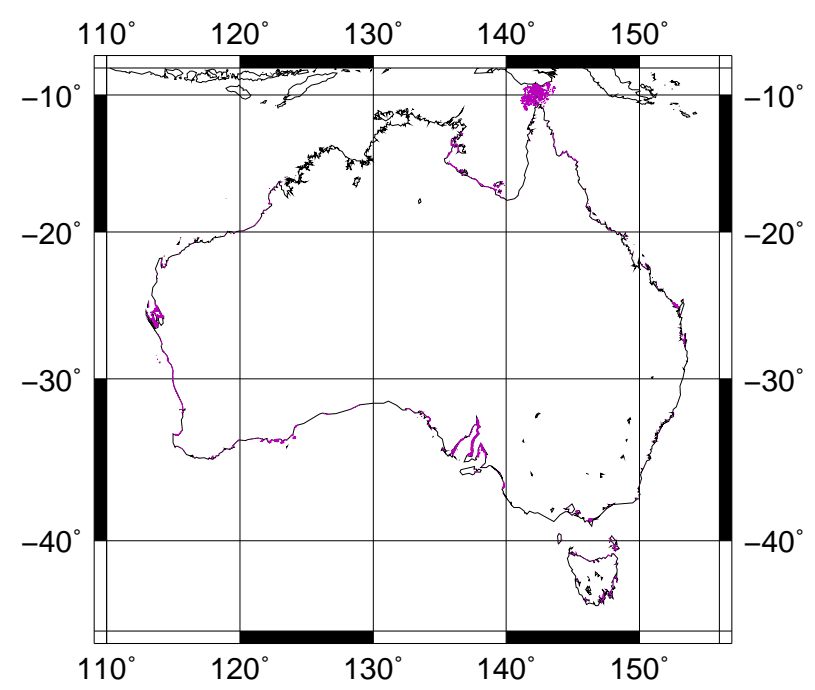

GMT 2006 Oct 19 14:41:05 Seagrass distribution according to cSIRO

Fig. 7. Top panel: Portion of the Australian coastal zone where irradiance does not limit the distribution of seagrasses (benthic irradiance $\geq 5.1 \mathrm{~mol}$ photons $\mathrm{m}^{-2} \mathrm{~d}^{-1}$ ). Bottom panel: Distribution of seagrasses along the Australian coastline estimated from field surveys (CSIRO, personal communication).

substrate suitability nor limiting factors other than light, suggest that the estimate of Charpy-Roubaud and Sournia (1990) of a global surface cover of $6 \times 10^{6} \mathrm{~km}^{2}$ is underestimated.

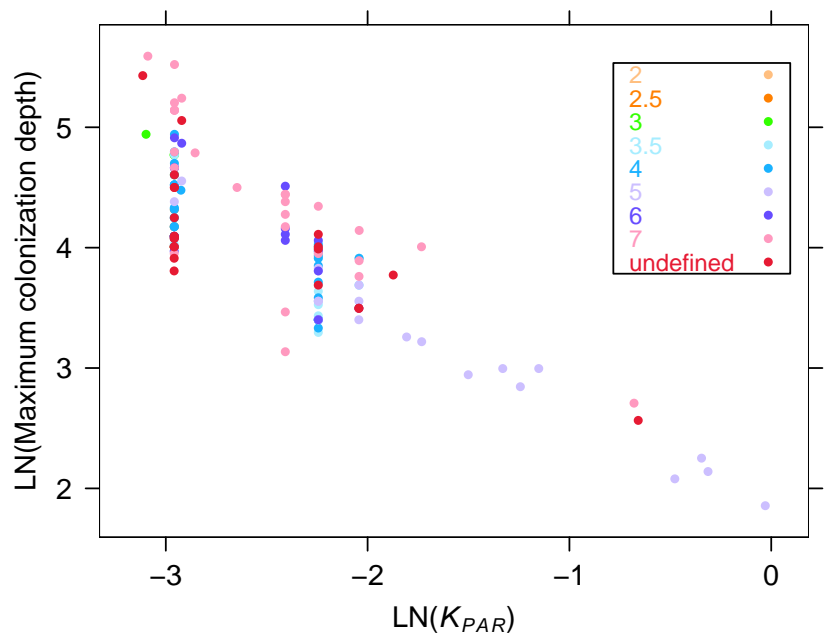

Fig. 8. Relationship between the colonization depth of marine algae $\left(Z_{c}\right.$ in $\left.\mathrm{m}\right)$ and the light attenuation coefficient of the overlying water column $\left(K_{\mathrm{PAR}}\right.$, in $\left.\mathrm{m}^{-1}\right)$. Definition of functional groups (Steneck and Dethier, 1994): 2, filamentous; 2.5 , slightly corticated filamentous algae; 3, foliose; 3.5: corticated foliose; 4, corticated; 5 , leathery; 6 , articulated calcareous; 7 , crustose. The undefined group comprises species which could not be attributed to one of the groups above. Data are available in Appendix D. The regression is: $\operatorname{LN}\left(Z_{c}\right)=1.81-0.884 \times L N\left(K_{\mathrm{PAR}}\right), r^{2}=0.71, N=149$, $P<2.2 \times 10^{-16}$

\section{Microphytobenthos}

Microphytobenthos comprises the microscopic algae living in soft-bottoms. However, it is not possible to distinguish unequivocally between living benthic microalgae and recently settled phytoplankton. "Apparently functional chlorophyll$a$ " was found at depths up to $285 \mathrm{~m}$ and transport seemed unlikely (Cahoon, 1986). If confirmed, this observation would be a new depth record for viable plants in the sea. According to Cahoon (1999), benthic microalgae may often extend deeper than $40 \mathrm{~m}$ and decline in abundance with increasing depth in non-polar regions. He also reported that microalgae can sustain growth at irradiances well below average irradiances of 5 to $10 \mu \mathrm{mol}$ photons $\mathrm{m}^{-2} \mathrm{~s}^{-1}$ and $1 \%$ surface incident radiation. There is, to our knowledge, no data on the in situ light requirements or maximum depth of distribution of specific microphytobenthic organisms. Hence, it is not possible to derive a minimum light requirement, as we have done with other groups of photosynthetic organisms, and provide an estimate of the surface area of the coastal ocean where light does not limit the distribution of microphytobenthos. The minimum irradiance at which community metabolism has been detected $\left(0.4 \mathrm{~mol} \mathrm{~m}^{-2} \mathrm{~d}^{-1}\right.$; Table 7$)$ can be used as a very conservative minimum light requirement. About $27 \%$ and $49 \%$ of the surface area, respectively covered by Case 1 and Case 2 waters in non-polar regions receive at least this irradiance level (Table 5). The corresponding estimates in 
Table 7. Parameters used to derive the daily compensation irradiance of the major photosynthetic coastal ecosystems. The regression parameters are: $x$, daily benthic irradiance $\left(E_{z}\right.$ in mol photons $\left.\mathrm{m}^{-2} \mathrm{~d}^{-1}\right)$ and $y$, instantaneous compensation irradiance of communities ( $E_{c}$ comm. in mol photons $\mathrm{m}^{-2} \mathrm{~s}^{-1}$ ), except for coral reefs where $y$ is the compensation irradiance of coral organisms $\left(E_{c}\right.$ phot. in percent of the highest value found in the data compiled). The minimum $E_{z}$ is the median of the minimum light requirements for seagrasses, macroalgae and corals whereas it corresponds, for microphytobenthos, to the lowest benthic irradiance at which community metabolism has been reported. $E_{c}$ comm. is the instantaneous or daily compensation irradiance at the minimum $E_{z}$.

\begin{tabular}{|c|c|c|c|c|}
\hline System & Regression $E_{c \text { comm vs. }} E_{z}$ & $\begin{array}{c}\text { Minimum } E_{z} \\
\left(\mathrm{~mol} \text { photons } \mathrm{m}^{-2} \mathrm{~d}^{-1}\right)\end{array}$ & $\begin{array}{l}\text { Instantaneous } E_{c} \text { comm. } \\
\left(\mu \mathrm{mol} \text { photons } \mathrm{m}^{-2} \mathrm{~s}^{-1}\right)\end{array}$ & $\begin{array}{c}\text { Daily } E_{c \text { comm. }} \\
\text { (mol photons } \mathrm{m}^{-2} \mathrm{~d}^{-1} \text { ) }\end{array}$ \\
\hline Seagrass beds & $y=5.457+4.448 \times x$ & 5.1 & 28.1 & 2.4 \\
\hline Algal beds & $y=18+1.356 \times x$ & 0.31 & 18.4 & 1.6 \\
\hline Microphytobenthos & $y=1.35+3.57 \times x$ & 0.4 & 2.8 & 0.24 \\
\hline Coral reefs & $y=19.6+20.81 \times L N(x)$ & 1.41 & 50.8 & 4.4 \\
\hline
\end{tabular}

the Arctic region are $14 \%$ and $36 \%$. Globally, extension of microphytobenthos is not light-limited in $33 \%$ of the global coastal ocean $\left(8.26 \times 10^{6} \mathrm{~km}^{2}\right)$.

\section{Corals and coral reefs}

Zooxanthellate scleractinian corals and alcyonarians are invertebrates harbouring photosynthetic microalgae inside their cells. They are, together with coralline macroalgae, the major contributors to the edification of coral reefs. Their horizontal range of distribution is primarily controlled by the $16^{\circ} \mathrm{C}$ isotherm (minimum winter temperature). Reefbuilding corals require some minimum light level, despite their ability to feed heterotrophically, and their depth distribution is primarily limited by PAR.

The depth distributions of corals, coral communities and coral reefs are confused by the ongoing discussion of what defines a coral community versus a coral reef. Most definitions of coral reefs imply a net positive $\mathrm{CaCO}_{3}$ accumulation, and do not consider the depth at which gross primary production $(G P P)$ exceeds carbon losses. However, it is likely that a coral community still contributes to net primary production, even if it does not produce an excess of calcium carbonate. Using depths where net calcification equals zero thus provides a conservative estimate of $E_{c}$ comm. For example, the most widely quoted figure for the depth limit to coral reef development is 30 to $40 \mathrm{~m}$ (e.g., Grigg and Epp, 1989), which in typical Case 1 waters with a $K_{\text {PAR }}$ of $0.04 \mathrm{~m}^{-1}$, equates to a maximum irradiance of about 400 to $600 \mu \mathrm{mol} \mathrm{m}^{-2} \mathrm{~s}^{-1}$. A model that estimated coral reef distribution as a function of PAR found that the global reef distribution was best simulated with a maximum PAR of 250 to $300 \mu \mathrm{mol} \mathrm{m}^{-2} \mathrm{~s}^{-1}$ (or 7 to $8 \mathrm{~mol} \mathrm{~m}^{-2} \mathrm{~d}^{-1}$; Kleypas, 1997). However, this reflects light control on reef formation (net $\mathrm{CaCO}_{3}$ production), and not necessarily organic carbon production. The recently discovered deep-water coral community at Pulley Ridge off the west coast of Florida $\left(24.80^{\circ} \mathrm{N}\right.$; $83.70^{\circ} \mathrm{W}$ ), occurs in waters 58 to $75 \mathrm{~m}$ deep (Jarrett et al., 2005). Provided that the SeaWiFS average daily PAR at this location is about $43 \mathrm{~mol} \mathrm{~m}^{-2} \mathrm{~d}^{-1}$, and assuming very clear water $\left(K_{\mathrm{PAR}}=0.04 \mathrm{~m}^{-1}\right)$, then average daily PAR at $60 \mathrm{~m}$ is about $3.9 \mathrm{~mol} \mathrm{~m}^{-2} \mathrm{~d}^{-1}$, about half the value estimated as necessary for net positive coral reef $\mathrm{CaCO}_{3}$ production.

According to our data compilation (Appendix F), the average benthic irradiance at the maximum depth of coral colonization is $1.2 \pm 1.7 \mathrm{~mol} \mathrm{~m}^{-2} \mathrm{~d}^{-1}$ ( \pm standard error of the mean; $N=30$ ) and the median is $0.35 \mathrm{~mol} \mathrm{~m}^{-2} \mathrm{~d}^{-1}$. In the non-polar region, an estimated $33 \%$ and $56 \%$ of the surface area covered by Case 1 and Case 2 waters, respectively, receive at least this irradiance level (Table 5).

Temperature is also a major control of the distribution of coral reefs as they do not occur where the average minimum weekly temperature is below $16^{\circ} \mathrm{C}$ (Kleypas et al., 1999). Using the OI.v2 weekly temperature data (Reynolds et al., 2002), we find that $1.5 \times 10^{6} \mathrm{~km}^{2}$ of the non-polar coastal zone has an average minimum temperature of $16^{\circ} \mathrm{C}$ and receives at least $1.41 \mathrm{~mol}$ photons $\mathrm{m}^{-2} \mathrm{~d}^{-1}$ and hence may be suitable for coral colonization.

\subsubsection{Surface area where net community production is pos- itive}

In this section, information on the behaviors of $E_{c}$ phot. and $E_{c}$ comm. as a function of benthic irradiance $\left(E_{z}\right)$ is compiled for the major photosynthetic organisms and ecosystems.

Considerable differences have been reported in the $P-E$ curves parameters of seagrasses. The main factors controlling $E_{c}$ phot. are: season, depth, sulphide levels, temperature and concentration of nutrients (Hemminga, 1998). Large changes were reported for Zostera marina with values of 1 and $17 \mu \mathrm{mol} \mathrm{m}^{-2} \mathrm{~s}^{-1}$, respectively in winter and summer (Dennison, 1987). A compilation of literature data suggests that $E_{c}$ phot. does not vary greatly across species and depth and ranges from 9 to $26 \mu \mathrm{mol} \mathrm{m}^{-2} \mathrm{~s}^{-1}$ in eight species of seagrasses collected at depths ranging from 0.5 to $33 \mathrm{~m}$ (Dennison, 1987; Masini et al., 1995). Olesen et al. (2002) found that $E_{c}$ phot. varies significantly with depth in Cymodocea nodosa but not in Posidonia oceanica but did not provide the 
Table 8. Percent surface area where benthic irradiance is higher that the daily community compensation irradiance (NPP $>0$ ). Data are not reported in the Arctic region for seagrasses communities nor for coral reefs where these groups are not present.

\begin{tabular}{lccccccc}
\hline & \multicolumn{3}{c}{ Non-polar region } & & Arctic region & \multicolumn{2}{c}{$\begin{array}{c}\text { Total surface area } \\
\left(10^{6} \mathrm{~km}^{2}\right)\end{array}$} \\
Community & Case 1 & Case 2 & Cases 1 and 2 & Case 1 & Case 2 & Cases 1 and 2 & \\
\hline Seagrass beds & 16 & 32 & 23 & - & - & - & 4.32 \\
Macroalgal communities & 18 & 36 & 26 & 8 & 23 & 13 & 5.71 \\
Microphytobenthic communities & 31 & 53 & 41 & 17 & 41 & 25 & -19 \\
Coral reefs & $8-13$ & $14-26$ & $11-19$ & - & - & - & - \\
\hline
\end{tabular}

actual data. $E_{c}$ phot. also varies considerably depending on which part of the plant is investigated. Hemminga and Duarte (2000) reported values 5 times higher for entire plants than for isolated leaf segments and Drew (1979) reported values ranging from 1 to $175 \mu \mathrm{mol} \mathrm{m}^{-2} \mathrm{~s}^{-1}$ for leaf segments.

$E_{c}$ phot. of seagrasses leaf segments do not always decrease as a function of decreasing benthic irradiance and can even increase slightly with depth (see inset in Fig. 6a). However, in contrast to other coastal ecosystems, some $E_{c}$ comm. data are available for seagrass communities at different $E_{z}$ values (Fig. 6a), with a statistically significant regression:

$$
E_{c \text { comm. }}=5.46+4.45 \times \text { depth; } N=5, r^{2}=0.92, P=0.01
$$

The data compilation (Sect. 4.2.2) indicates that the median value of the minimum light requirement of seagrasses is $5.1 \mathrm{~mol}$ photons $\mathrm{m}^{-2} \mathrm{~d}^{-1}$. Extending the regression line suggests that at this $E_{z}$ value, $E_{c}$ comm. is $28.1 \mu \mathrm{mol} \mathrm{m}^{-2} \mathrm{~s}^{-1}$ or $1.2 \mathrm{~mol}$ photons $\mathrm{m}^{-2} \mathrm{~d}^{-1}$ (Table 7). The sea bottom of about $16 \%$ and $32 \%$ of the surface area respectively covered by Case 1 and Case 2 waters in non-polar regions receive at least this irradiance level (Table 8). Globally, net community production of seagrass beds can be positive in about $23 \%\left(4.319 \times 10^{6} \mathrm{~km}^{2}\right)$ of the coastal non-polar region. This estimate is almost 10 times larger than the estimated potential seagrass extent of 0.5 to $0.6 \times 10^{6} \mathrm{~km}^{2}$ and the documented $0.15 \times 10^{6} \mathrm{~km}^{2}$ occupied by seagrasses (Duarte and Chiscano, 1999; Green and Short, 2003). This suggests that the seagrass extent is much larger than previously considered, as previous estimates were based on rather rough assumptions, compared to the rigorous and global assessment of underwater irradiance levels in the coastal ocean provided, for the first time, here.

Macroalgae are important contributors to coastal primary production (Gattuso et al., 1998), including in polar regions despite the low annual primary production. For example, net primary production of Laminaria saccharina, which comprises only 5 to $10 \%$ of the macroalgal biomass, can reach $0.1 \mathrm{~mol} \mathrm{C} \mathrm{m} \mathrm{yr}^{-1}$ as compared to a pelagic value of $0.8 \mathrm{~mol} \mathrm{C} \mathrm{m}^{-2} \mathrm{yr}^{-1}$ (Rysgaard et al., 1999). There are quite numerous examples of decreasing macroalgal $E_{c}$ phot. with increasing depth but few studies provide information on the light attenuation (e.g., Johansson and Snoeijs, 2002). $E_{c}$ phot. of macroalgae (including epilithic algae) also does not always decrease as a function of decreasing benthic irradiance. It is sometimes relatively constant or slightly increases (see inset in Fig. 6b). In contrast to other coastal ecosystems, some $E_{c}$ comm. data are available for macroalgal communities at different $E_{z}$ values (Fig. 6b). These data exhibit a statistically significant regression:

$$
E_{c \text { comm. }}=17.8+1.356 \times \text { depth } ;=22, r^{2}=0.69, \quad P<0.001
$$

The compilation of data provided in Appendix D indicates that the grand median value of the minimum light requirement of macroalgae is $0.31 \mathrm{~mol}$ photons $\mathrm{m}^{-2} \mathrm{~d}^{-1}$. At this value of benthic irradiance, $E_{c}$ comm. is $18.4 \mu \mathrm{mol} \mathrm{m}^{-2} \mathrm{~s}^{-1}$ or $1.6 \mathrm{~mol}$ photons $\mathrm{m}^{-2} \mathrm{~d}^{-1}$ (Table 7). The sea bottom of about $26 \%$ and $13 \%\left(4.89 \times 10^{6}\right.$ and $\left.0.81 \times 10^{6} \mathrm{~km}^{2}\right)$ of the surface areas covered by Cases 1 and 2 waters, respectively in the non-polar and Arctic coastal regions, receive at least this irradiance level (Table 8). Therefore the $N C P$ of macroalgal communities can be positive in $23 \%\left(5.71 \times 10^{6} \mathrm{~km}^{2}\right)$ of the global coastal ocean. These results indicate, together with the estimates of potential irradiance to support seagrass above, that the area occupied by marine macrophytes is likely to be much larger, by a factor of 3 to 4 fold, than previously estimated and that, consequently, the importante of benthic autotrophs on the oceanic carbon budget (cf. Duarte et al., 2005) has been underestimated.

A comprehensive review of the contribution of benthic microalgae in neritic ecosystems pointed out that relatively few studies provide compensation irradiance or compensation depth of benthic microalgae (Cahoon, 1999). We found none for individual species in situ but measurements of community metabolism have been measured over a wide range of benthic irradiance (Fig. 6c). The lowest irradiance at which gross primary production was measured is $0.5 \mu \mathrm{mol}$ photons $\mathrm{m}^{-2} \mathrm{~s}^{-1}$ (Palmisano et al., 1985, in Cahoon, 1999). In our data compilation, the instantaneous $E_{c}$ comm. ranges from 0.6 to $139.5 \mu \mathrm{mol}$ photons $\mathrm{m}^{-2} \mathrm{~s}^{-1}$ (Appendix F). The euphotic zone may extend 2 to $2.5 \mathrm{~mm}$ deep into the sediment (Jahnke et al., 2000) and $E_{c}$ comm. values, which are based on irradiance measurements above the sediment surface, are 
thus overestimated. The instantaneous $E_{c \text { comm. declines as a }}$ function of depth according to the following relationship:

$$
E_{c}=1.35+3.57 \times \text { depth } r^{2}=0.61, N=17, \quad P=0.002
$$

Based on this relationship and on the lowest irradiance at which a positive $N C P$ has been reported (Table 7 ), about $41 \%$ $\left(7.67 \times 10^{6} \mathrm{~km}^{2}\right)$ of the non-polar region (31 and $53 \%$ or 5.78 and $10.05 \times 10^{6} \mathrm{~km}^{2}$ in Case 1 and 2 waters, respectively) receives enough light to support a positive microphytobentic $N C P$; and, in the Arctic region, 17 and $41 \%$ of the surface area respectively covered by Case 1 and Case 2 waters receive at least this irradiance level (Table 5). Cahoon (1999) estimated that gross primary production of microphytobenthos occurs down to $0.1 \%$ of surface irradiance or a depth of 66 to $100 \mathrm{~m}$. We estimate, using the ETOPO2 data set, that this depth range represents 39 to $22 \%$ of the coastal ocean. Richards et al. (2006, data interpolated from their Fig. 6) collected an impressive data set in the South Atlantic Bight and provided the following relationship between microphytobenthic net community production (NCP in mmol $\mathrm{C} \mathrm{m}^{-2} \mathrm{~d}^{-1}$ ) and benthic irradiance $\left(E_{z}\right.$ in mol photons $\left.\mathrm{m}^{-2} \mathrm{~d}^{-1}\right)$ :

$N C P=-7.64+20.91 \times E_{z}$

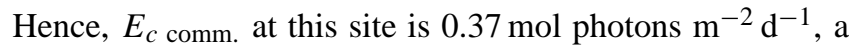
value that is almost identical to the value found in our data compilation $\left(0.4 \mathrm{~mol}\right.$ photons $\left.\mathrm{m}^{-2} \mathrm{~d}^{-1}\right)$. No negative $N C P$ data is reported, but Jahnke et al. (2000) reported an average community respiration of $34.75 \mathrm{mmol} \mathrm{C} \mathrm{m}^{-2} \mathrm{~d}^{-1}$ for the same area. Glud et al. (2002) has shown that net primary production is saturated at irradiances close to the highest irradiance measured in situ. Assuming that primary production is saturated at a value close to the highest $E_{z}$ investigated by Richards et al. (2006, $4 \mathrm{~mol}$ photons $\left.\mathrm{m}^{-2} \mathrm{~d}^{-1}\right)$ and hence that the maximum gross primary production is $120.82 \mathrm{mmol}$ $\mathrm{C} \mathrm{m}^{-2} \mathrm{~d}^{-1}$, the following $P-E$ curve is derived:

$N C P=120.82 \times\left(1-e^{-\frac{E_{z}}{2.09}}\right)-34.75$

Combining Eq. (6) and the global distribution of benthic irradiance enables to derive upper limits of the global net and gross primary production of microphytobenthos of $2.7 \times 10^{13}$

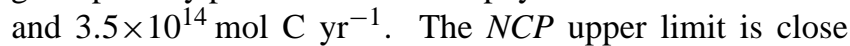
to the NCP estimates reported by Charpy-Roubaud and Sournia (1990, $\left.2.8 \times 10^{13} \mathrm{~mol} \mathrm{C} \mathrm{yr}^{-1}\right)$ and Cahoon (1999, $\left.4.2 \times 10^{13} \mathrm{~mol} \mathrm{C} \mathrm{yr}^{-1}\right)$.

Individual corals are known to occur to depths greater than $100 \mathrm{~m}$, due to a combination of photo-acclimation, increased heterotrophy, and other adaptations (Table 3). Photoacclimation to decreasing irradiance is well documented in many corals. The data compiled in Appendix F (shown in the inset of Fig. 6d), demonstrate a significant relationship between $E_{c}$ (expressed as percent of the largest $E_{c}$ ) and $E_{z}$ :

$E_{c}=19.6+20.81 \times L N\left(E_{z}\right) ; r^{2}=0.58, n=48, \quad P<0.001$
Measurements of instantaneous $E_{c}$ comm. have only been performed on reef flats shallower than $2 \mathrm{~m}$, hence at relatively high $E_{z}$ (Fig. 6d). The mean instantaneous $E_{c \text { comm. of }}$ $184 \mu \mathrm{mol}$ photons $\mathrm{m}^{-2} \mathrm{~s}^{-1}$ or a daily $E_{c \text { comm. }}$ of $16 \mathrm{~mol}$ photons $\mathrm{m}^{-2} \mathrm{~d}^{-1}$ (Fig. 6d). Adjusting this value to account for photo-acclimation of reef communities, $E_{c}$ comm. ranges from 4.4 to $16 \mathrm{~mol}$ photons $\mathrm{m}^{-2} \mathrm{~d}^{-1}$ (respectively, with maximum or no photoacclimation; see Sect. 4.2.1). In waters of typical reef clarity $\left(K_{\mathrm{PAR}}=0.06 \mathrm{~m}^{-1}\right)$ and surface PAR (40 mol photons $\mathrm{m}^{-2} \mathrm{~d}^{-1}$ ), this irradiance corresponds to a depth of 15 to $37 \mathrm{~m}$. Thus, although coral reef structures are known to extend down to $100 \mathrm{~m}$ depth, and corals and communities even deeper, the maximum depth where NPP remains positive is significantly shallower. This is consistent with observations of the depth limitations of robust reef growth. For example, a threshold for reef building exists at about $50 \mathrm{~m}$ depth in the Au'au Channel (Hawaii) despite a depth distribution of the main reef building coral species which extends to about 80 to $100 \mathrm{~m}$ (Grigg, 2006). Based on this analysis, $11-19 \%\left(2-3.5 \times 10^{6} \mathrm{~km}^{2}\right)$ of the non-polar shelves receive sufficient light to support a positive NPP for coral reefs.

Temperature is also a major control of the distribution of coral reefs as they do not occur where the average minimum weekly temperature is below $16^{\circ} \mathrm{C}$ (Kleypas et al., 1999). Combining benthic irradiance with the OI.v2 weekly temperature data (Reynolds et al., 2002), we find that $1.2 \times 10^{6} \mathrm{~km}^{2}$ of the coastal zone has an average minimum temperature of $16^{\circ} \mathrm{C}$ and receives at least $4.4 \mathrm{~mol}$ photons $\mathrm{m}^{-2} \mathrm{~d}^{-1}$ and hence exhibit a positive carbon balance. This is an upper limit to the global extension of coral reefs. Regional and global values of the coral reef areas have been estimated either using a depth threshold of 30 to $183 \mathrm{~m}$ (e.g. Smith, 1978; Rohmann et al., 2005) or maps of the actual distribution of coral reefs (Spalding and Grenfell, 1997; Spalding et al., 2001). Our data suggests that some of the estimates which range from $112 \times 10^{3}$ to $3930 \times 10^{3} \mathrm{~km}^{2}$ (Spalding and Grenfell, 1997) are greatly overestimated.

\section{Conclusion and perspectives}

This is the first study to provide a global perspective of the distribution of light in the coastal ocean, the light limitation of the distribution of benthic photosynthetic organisms and metabolic performances of benthic photosynthetic ecosystems. State-of-the-art data sets and methods were used, yet there are several limitations (see Sect. 4.1) related to the spatial resolution of the satellite data, the parameterization used to convert reflectance data to irradiance, the lack of global information on the benthic nepheloid layer, and the relatively limited biological information available.

Better accuracy of satellite data will soon be available thanks to newer sensors with increased number of spectral bands, such as the Moderate Resolution Imaging 
Spectroradiometer (MODIS), consideration of the light direction and polarization, and improved parameterization of $K_{\text {PAR }}$ using more extensive field data. Semi-analytical algorithms used to derive the concentration of chlorophyll from ocean color (e.g., Maritorena et al., 2002) perform better than the empirical relationships used here when multiple factors control ocean color, such as in Case 2 waters. However, they tend to fail in highly turbid waters (Hu et al., 2004). Regional models perform much better (e.g. Bricaud et al., 2002) but cannot be extended to the global scale. One possible option, presently beyond reach, would be to develop a global typology of the optical characteristics of the ocean and apply regional models in each of the regions identified.

Estimate of the global distribution of benthic irradiance would greatly benefit from a better understanding of processes in the benthic boundary layer (R. Jahnke, personal communication). Suspended particles very near the sea floor are not captured by remote sensing nor by measurements of the Secchi disk depth. Yet, they may significantly reduce light fluxes at the bottom. Irradiance data collected at the sea floor would provide ground truth of estimates derived using remote sensing data.

There are relatively few investigations of the depth limit of photosynthetic organisms mostly due to limitations of diving and the high cost of exploring by submarine and remotely operated vehicles. It is likely that the maximum depth of colonization will increase as the exploration effort will continue. However, this not likely to change our conclusions on community metabolism.

The daily compensation irradiance of benthic communities ranges from 0.24 to 4.4 mol photons $\mathrm{m}^{-2} \mathrm{~d}^{-1}$ (Table 7), within the range reported for phytoplankton populations in the field and in culture (respectively 0.1 to 1.7 and 0.06 to $1.8 \mathrm{~mol}$ photons $\mathrm{m}^{-2} \mathrm{~d}^{-1}$; reviewed by Marra, 2004). Planktonic $E_{c}$ comm. must be much higher because these estimates do not take into account respiration of planktonic heterotrophs. The relatively small difference in $E_{c}$ comm. between planktonic and benthic communities indicates that photoacclimation mechanisms of benthic photoautotrophs is more effective than in planktonic photoautotrophs. Large benthic primary producers are fixed at a given depth, offering greater opportunities for photoaclimatation than for phytoplankton, which may be mixed vertically and thereby experiencing a changing light field, precluding efficient photoaclimatation. Benthic microalgae may migrate within the sediment to optimize their photosynthesis.

The horizontal distribution of marine benthic primary producers is controlled by numerous processes but the vertical (depth) distribution is mostly controlled by light, the scraping effect of pack-ice and the quality of the substrate. Unfortunately, the effects of substrate quality on the global distribution of benthic primary producers is currently hindered by the lack of a comprehensive database on substrate types. The most advanced database available, dbSEABED (http://instaar.colorado.edu/ $\sim$ jenkinsc/dbseabed/dbseabed.html), provides the best opportunity for this kind of analysis, and although its geographic coverage is increasing rapidly, it currently covers less than $1 \%$ of the coastal ocean (C. Jenkins, personal communication). Jahnke et al. (2000) concluded that benthic gross primary production can occur over $84 \%$ of the surface area of the Southeastern U.S. continental shelf. Nelson et al. (1999) estimated that benthic primary production may occur over 80 to $90 \%$ of the shelf width of the South Atlantic Bight. Our results indicate that positive benthic net community production can occur over $33 \%$ of the global shelf area (using $E_{c}$ comm. of microphythobenthic communities; Table 7).

The temporal scale was not addressed in this study despite its obvious importance. At time scale smaller than one year, changes in irradiance and other parameters such as temperature and concentrations of nutrients control control community metabolism. At longer time scales, sediment delivery is affected by human activities in opposite directions. The loading of terrestrial sediment to aquatic environments has increased in many areas as a result of logging and land use changes (Milliman and Meade, 1983). Increased anthropogenic sediment retention on land Vörösmarty et al. (2003) also occurs but is more geographically localized. A statistically significant shallowing of the average depth of Case 2 waters was found, without any increase of their surface area (data not shown). This trend may be related to sediment retention but certainly needs to be confirmed with a study duration longer that 5 years. The uncertainties of the benthic irradiance are such that year-to-year differences in light penetration are dubious. Temporal changes in light penetration are nevertheless of potential considerable importance because of possible changes in turbidity and coverage of macrophytes by periphyton as a result of eutrophication (e.g. Silberstein et al., 1986). Both could cause a dramatic decline in the extent of macrophytes. Polar regions will also be likely affected due to the increased delivery of turbid meltwater that is expected (Borum et al., 2002). Several reports suggest that the maximum depth of colonization of macrophytes has declined in past decades. For example, the deepest specimens of the alga Fucus vesiculosus at one location of the coast of Finland were found at $8-10 \mathrm{~m}$ depth in the $1930 \mathrm{~s}$ and at $5 \mathrm{~m}$ depth in 1994 (Bäck and Ruuskanen, 2000, and references therein).

\section{Appendix A}

\section{Distribution of Case 1 and Case 2 waters}

Data are provided as a zipped text file (http://www. biogeosciences.net/3/489/2006/bg-3-489-2006-supplement. zip: bg-2006-0034-sp1) with fields separated by a space character. The columns are: longitude and latitude in decimal degree, depth ( $\mathrm{m}$; as negative values) and the water type. The later is the average of the monthly water types and therefore ranges from 1 (Case 1 waters every month) 
to 2 (Case 2 waters every month). Only 5 months (June to October) are considered North of $60^{\circ} \mathrm{N}$.

\section{Appendix B}

\section{Distribution of benthic irradiance}

Data are provided as a zipped text file (http://www. biogeosciences.net/3/489/2006/bg-3-489-2006-supplement. zip: bg-2006-0034-sp2) with fields separated by a space character. The columns are: longitude and latitude in decimal degree, depth ( $\mathrm{m}$; as negative values) and benthic irradiance ( $\mathrm{mol}$ photons $\mathrm{m}^{-2} \mathrm{~d}^{-1}$ ). Benthic irradiance is an average value based on all $K_{\text {PAR monthly data available for }}$ each pixel ( 5 monthly data North of $60^{\circ} \mathrm{N}$ to 12 monthly data in most of the region from $60^{\circ} \mathrm{S}$ to $60^{\circ} \mathrm{N}$ ).

\section{Appendix C}

\section{Maximum depth of colonization of seagrasses and optical data}

Data are provided as a text file (http://www.biogeosciences. net/3/489/2006/bg-3-489-2006-supplement.zip: bg-20060034-sp3) with fields separated by commas (CSV). The columns are: species name, location of the study site (longitude and latitude in decimal degree), depth (m), light attenuation coefficient $\left(K_{\mathrm{PAR}}\right)$, surface irradiance (mol photons $\mathrm{m}^{-2} \mathrm{~d}^{-1}$ ), benthic irradiance (mol photons $\mathrm{m}^{-2} \mathrm{~d}^{-1}$ ), benthic irradiance (percent of surface irradiance), and the reference. Benthic irradiance is the value reported by the authors or was calculated using SeaWiFS PAR and either the light attenuation coefficient or the percent light transmission. The blank line separates the data originally compiled by Duarte (1991) from those compiled for this paper.

\section{Appendix D}

\section{Maximum depth of colonization of macroalgae and optical data}

Data are provided as a text file (http://www.biogeosciences. net/3/489/2006/bg-3-489-2006-supplement.zip: bg-20060034-sp4) with fields separated by commas (CSV). The columns are: species name, functional group according to Steneck and Dethier (1994), location of the study site (longitude and latitude in decimal degree), depth (m), percent irradiance, benthic irradiance (mol photons $\mathrm{m}^{-2} \mathrm{~d}^{-1}$, surface irradiance (mol photons $\mathrm{m}^{-2} \mathrm{~d}^{-1}$ ) and the reference. Benthic irradiance is the value reported by the authors or was calculated using SeaWiFS PAR and either the light attenuation coefficient or the percent light transmission.

\section{Appendix E}

\section{Maximum depth of colonization of scleractinian corals and optical data}

Data are provided as a text file (http://www.biogeosciences. net/3/489/2006/bg-3-489-2006-supplement.zip: bg-20060034-sp5) with fields separated by commas (CSV). The columns are: species name, location of the study site (longitude and latitude in decimal degree), depth $(\mathrm{m}), K_{\mathrm{PAR}}\left(\mathrm{m}^{-1}\right)$, surface irradiance (mol photons $\mathrm{m}^{-2} \mathrm{~d}^{-1}$ ), benthic irradiance (mol photons $\mathrm{m}^{-2} \mathrm{~d}^{-1}$ ) and the reference. Benthic irradiance is the value reported by the authors or was calculated using SeaWiFS PAR and either the light attenuation coefficient or the percent light transmission.

\section{Appendix F}

\section{Benthic and compensation irradiances in photosyn- thetic organisms and communities}

Data are provided as a text file (http://www.biogeosciences. net/3/489/2006/bg-3-489-2006-supplement.zip: bg-20060034-sp6) with fields separated by commas (CSV). The columns are: species name or community (when applicable), benthic irradiance (mol photons $\mathrm{m}^{-2} \mathrm{~d}^{-1}$, instantaneous compensation irradiance $\left(\mu \mathrm{mol}\right.$ photons $\mathrm{m}^{-2} \mathrm{~s}^{-1}$ ) and the reference. This compilation is as thorough as possible but is probably not exhaustive. The compensation irradiance is only reported when benthic irradiance was reported by the authors or when either the light attenuation coefficient or the percent light transmission was available. The surface irradiance was derived from SeaWiFS PAR when no value was reported by the authors.

Acknowledgements. This research was supported by the European Union (EU) in the framework of the EUROTROPH project (contract \#EVK3-CT-2000-00040), and through a CNRS/CSIC cooperative agreement. It is a contribution to the Networks of Excellence MARBEF and EUROCEANS, and the Integrated Project CARBOOCEAN (contract \#511176 (GOCE)). B. Steneck provided invaluable assistance for assigning algal species into functional groups and kindly corrected spelling mistakes in Appendix D. We gratefully thank W. W. Gregg and N. W. Casey for supplying the data shown in Fig. 2, M. Abe, J. Borum and F. Gohin for contributing data sets, W. H. F. Smith for sending information on the registration error of the ETOPO2 data set, and C. Jenkins for providing considerable data and information on dbSEABED. The SeaWiFS Level-3 data have been obtained through the Goddard Distributed Active Archive Center (GES-DAAC) at the NASA Goddard Space Flight Center, which is duly acknowledged. The seagrass distribution around the Australian coastline was prepared by H. Kirkman (CSIRO Division of Fisheries) from a review of published and unpublished sources, and updated by I. Hahmdorf (Bureau of Rural Sciences). J.-P. Gattuso gratefully acknowledges NCAR and CNRS for sabbatical support. The constructive 
comments of R. Jahnke and J. Nelson improved an earlier draft of this paper.

Edited by: E. Boss

\section{References}

Ackleson, S.: Light in shallow waters: A brief research review, Limnol. Oceanogr., 48, 323-328, 2003.

Agegian, C. R. and Abbott, I. A.: Deep water macroalgal communities: a comparison between Penguin Bank (Hawaii) and Johnston Atoll, in: Proc. 5th Int. Coral Reef Cong., vol. 5, pp. 47-50, 1985.

Anthony, K., Ridd, P., Orpin, A., Larcombe, P., and Lough, J.: Temporal variation of light availability in coastal benthic habitats: Effects of clouds, turbidity, and tides, Limnol. Oceanogr., 49, 2201-2211, 2004.

Banse, K.: Should we continue to use the $1 \%$ light depth convention for estimating the compensation depth of phytoplankton for another 70 years?, Limnol. Oceanogr. Bull., 13, 49-52, 2004.

Barnes, D. J.: Seasonality in community productivity and calcification at Davies Reef, Central Great Barrier Reef, Proc. 6th Int. Coral Reef Symp., pp. 521-527, 1988.

Barnes, D. J. and Devereux, M. J.: Productivity and calcification on a coral reef: a survey using $\mathrm{pH}$ and oxygen electrode techniques, J. Exp. Mar. Biol. Ecol., 79(3), 213-231, 1984.

Bäck, S. and Ruuskanen, A.: Distribution and maximum growth depth of Fucus vesiculosus along the Gulf of Finland, Mar. Biol., 136, 303-307, 2000.

Borum, J. and Sand-Jensen, K.: Is total primary production in shallow coastal marine waters stimulated by nitrogen loading?, Oikos, 76, 406-410, 1996.

Borum, J., Pedersen, M., Krause-Jensen, D., Christensen, P., and Nielsen, K.: Biomass, photosynthesis and growth of Laminaria saccharina in a high-arctic fjord, NE Greenland, Mar. Biol., 141, 11-19, 2002.

Boucher, G., Clavier, J., Hily, C., and Gattuso, J.-P.: Contribution of soft-bottoms to the community metabolism (carbon production and calcification) of a barrier reef flat (Moorea, French Polynesia), J. Exp. Mar. Biol. Ecol., 225, 269-283, 1998.

Bricaud, A., Bosc, E., and Antoine, D.: Algal biomass and sea surface temperature in the Mediterranean Basin - Intercomparison of data from various satellite sensors, and implications for primary production estimates, Remote Sens. Environ., 81(2-3), 163-178, 2002.

Cahoon, L.: Depth range of benthic microalgae off North Carolina, in: Joint meeting of the American Society for Limnology and Oceanography and the Phycological Society of America, p. 16, University of Rhode Island, Kingston, USA, 1986.

Cahoon, L. B.: The role of benthic microalgae in neritic systems, Oceanography and Marine Biology: an Annual Review, 37, 4786, 1999.

Cahoon, L. B., Beretich, G. R., J., Thomas, C. J., and McDonald, A. M.: Benthic microalgal production at Stellwagen Bank, Massachusetts Bay, USA, Mar. Ecol. Prog. Ser., 102(1-2), 179-185, 1993.

Campbell, J., Blasidell, J., and Darzi, M.: Level-3 SeaWiFS data products: spatial and temporal binning algorithms, in: NASA Technical Memorandum 104566, vol. 32, edited by: Hooker, S.,
Firestone, E., and Acker, J., pp. 1-73, NASA Goddard Space Flight Center, Greenbelt, Maryland, 1995.

Carpenter, R. C.: Relationships between primary production and irradiance in coral reef algal communities, Limnol. Oceanogr., 30(4), 784-793, 1985.

Carruthers, T., Dennison, W., Longstaff, B., Waycott, M., Abal, E., McKenzie, L., and Lee Long, W.: Seagrass habitats of northeast Australia: Models of key processes and controls, Bull. Mar. Sci., 71, 1153-1169, 2002.

Chalker, B. E. and Dunlap, W. C.: Primary production and photoadaptation by corals on the Great Barrier reef, in: Proc. Inaugural Great Barrier Reef Conference, edited by: Baker, J. T., Carter, R. W., Sammarco, P. W., and Stark, K. P., pp. 293-298, JCU Press, Townsville, 1983.

Charpy-Roubaud, C. and Sournia, A.: The comparative estimation of phytoplanktonic, microphytobenthic and macrophytobenthic primary production in the oceans, Marine Microbial Food Webs, 4(1), 31-57, 1990.

Cheshire, A. C., Westphalen, G., Wenden, A., Scriven, L. J., and Rowland, B. C.: Photosynthesis and respiration of phaeophycean-dominated macroalgal communities in summer and winter, Aquatic Botany, 55(3), 159-170, 1996.

Chisholm, J. R. M.: Primary productivity of reef-building crustose coralline algae, Limnol. Oceanogr., 48(4), 1376-1387, 2003.

Chisholm, J. R. M. and Jaubert, J. M.: Photoautotrophic metabolism of Caulerpa taxifolia (Chlorophyta) in the NW Mediterranean, Mar. Ecol. Prog. Ser., 153, 113-123, 1997.

Claustre, H. and Maritorena, S.: The many shades of ocean blue, Science, 302, 1514-1515, 2003.

Conkright, M. E., Levitus, S., O'Brien, T., Boyer, T. P., Stephens, C., Johnson, D., Baranova, O., Antonov, J. I., Gelfeld, R., Rochetser, J., and Forgy, C.: World Ocean Database Version 2.0, NODC Internal Report 14, 1999.

Dean, T. and Jacobsen, F.: Growth of juvenile Macrocystis pyrifera (Laminariales) in relation to environmental-factors, Mar. Biol., 83, 301-311, 1984.

Delesalle, B., Pichon, M., Frankignoulle, M., and Gattuso, J.-P.: Effects of a cyclone on coral reef phytoplankton biomass, primary production and composition (Moorea island, French Polynesia), J. Plankton Res., 15, 1413-1423, 1993.

Den Hartog, C.: The seagrasses of the world, North Holland Publishing Company, Amsterdam, 1970.

Dennison, W. C.: Effects of light on seagrass photosynthesis, growth and distribution, Aquatic Botany, 27, 15-26, 1987.

Dennison, W. C. and Alberte, R. S.: Photoadaptation and growth of Zostera marina L. (eelgrass) transplants along a depth gradient, J. Exp. Mar. Biol. Ecol., 98, 265-282, 1986.

Drew, E. A.: Factors affecting photosynthesis and its seasonal variation in the seagrasses Cymodocea nodosa (Ucria) Aschers, and Posidonia oceanica (L.) Delile in the Mediterranean, J. Exp. Mar. Biol. Ecol., 31, 173-194, 1978.

Drew, E. A.: Physiological aspects of primary production in seagrasses, Aquatic Botany, 7, 139-150, 1979.

Dring, M. J. and Lüning, K.: Influence of spring-neap tidal cycles on the light available for photosynthesis by benthic marine plants, Mar. Ecol. Prog. Ser., 104(1-2), 131-137, 1994.

Duarte, C.: Seagrass depth limits, Aquatic Botany, 40, 363-377, 1991. 
Duarte, C. M. and Chiscano, C. L.: Seagrass biomass and production: a reassessement, Aquatic Botany, 65, 159-174, 1999.

Duarte, C. M., Middelburg, J. J., and Caraco, N.: Major role of marine vegetation on the oceanic carbon cycle, Biogeosciences, $2,1-8,2005$, http://www.biogeosciences.net/2/1/2005/.

Erftemeijer, P. L. A., Osinga, R., and Mars, A. E.: Primary production of seagrass beds in south Sulawesi (Indonesia): a comparison of habitats, methods and species, Aquatic Botany, 46, 67-90, 1993.

Fabricius, K. E. and Klumpp, D. W.: Widespread mixotrophy in reef-inhabiting soft corals: the influence of depth, and colony expansion and contraction on photosynthesis, Mar. Ecol. Prog. Ser., 125(1-3), 195-204, 1995.

Fairhead, V. and Cheshire, A.: Seasonal and depth related variation in the photosynthesis-irradiance response of Ecklonia radiata (Phaeophyta, Laminariales) at West Island, South Australia, Mar. Biol., 145, 415-426, 2004.

Frouin, R., Franz, B., and Werdell, P.: The SeaWiFS PAR product, in: NASA Technical Memorandum 2003-206892, vol. 22, edited by: Hooker, S. and Firestone, E., pp. 1-74, NASA Goddard Space Flight Center, Greenbelt, Maryland, 2003.

Gacia, E., Kennedy, H., Duarte, C., Terrados, J., Marbà, N., Papadimitriou, S., and M. Fortes, M.: Light-dependence of the metabolic balance of a highly productive Philippine seagrass community, J. Exp. Mar. Biol. Ecol., 316, 55-67, 2005.

Gall, M.: Measurements to determine extinction coefficients and temperature gradients in the North Sea and English Channel, J. Mar. Biol. Assoc. UK, 28, 757-780, 1949.

Gattuso, J.-P. and Jaubert, J.: Features of depth effects on Stylophora pistillata, an hermatypic coral in the Gulf of Aqaba (Jordan, Red Sea), Proc. 5th Int. Coral Reef Cong., 6, 95-100, 1985.

Gattuso, J.-P., Pichon, M., Delesalle, B., Canon, C., and Frankignoulle, M.: Carbon fluxes in coral reefs. 1. Lagrangian measurement of community metabolism and resulting air-sea CO2 disequilibrium, Mar. Ecol. Prog. Ser., 145, 109-121, 1996.

Gattuso, J.-P., Frankignoulle, M., and Wollast, R.: Carbon and carbonate metabolism in coastal aquatic ecosystems, Annual Review of Ecology and Systematics, 29, 405-434, 1998.

Gerard, V. A.: Ecotypic differentiation in light-related traits of the kelp Laminaria saccharina, Mar. Biol., 97, 25-36, 1988.

Glud, R. N., Kuhl, M., Wenzhofer, F., and Rysgaard, S.: Benthic diatoms of a high Arctic fjord (Young Sound, NE Greenland): importance for ecosystem primary production, Mar. Ecol. Prog. Ser., 238, 15-29, 2002.

Gómez, I., Weykam, G., Klöser, H., and Wiencke, C.: Photosynthetic light requirements, metabolic carbon balance and zonation of sublittoral macroalgae from King George Island (Antarctica), Mar. Ecol. Prog. Ser., 148, 281-293, 1997.

Green, E. P. and Short, F. T.: World atlas of seagrasses, University of California Press, Berkeley, 2003.

Gregg, W. and Casey, N.: Global and regional evaluation of the SeaWiFS chlorophyll data set, Remote Sens. Environ., 93, 463479, 2004.

Grigg, R.: Depth limit for reef building corals in the Au'au Channel, SE Hawaii, Coral Reefs, 25, 77-84, 2006.

Grigg, R. W. and Epp, D.: Critical depth for the survival of coral islands: Effects on the Hawaiian Archipelago, Science, 243, 638$641,1989$.
Hata, H., Kudo, S., Yamano, H., Kurano, N., and Kayanne, H.: Organic carbon flux in Shiraho coral reef (Ishigaki Island, Japan), Mar. Ecol. Prog. Ser., 232, 129-140, 2002.

Hemminga, M.: The root/rhizome system of seagrasses: an asset and a burden, J. Sea Res., 39, 183-196, 1998.

Hemminga, M. and Duarte, C.: Seagrass ecology, Cambridge University Press, Cambridge, UK, 2000

Herndl, G. J., Peduzzi, P., and Fanuko, N.: Benthic community metabolism and microbial dynamics in the Gulf of Trieste (northern Adriatic Sea), Mar. Ecol. Prog. Ser., 53(2), 169-178, 1989.

Herzka, S. Z. and Dunton, K. H.: Seasonal photosynthetic patterns of the seagrass Thalassia testudinum in the western Gulf of Mexico, Mar. Ecol. Prog. Ser., 152, 103-117, 1997.

Højerslev, N. K. and Aarup, T.: Optical measurements on the Louisiana shelf off the Mississipi river, Estuarine Coast. Shelf Sci., 55, 599-611, 2002.

Holmes, R. W.: The Secchi disk in turbid coastal waters, Limnol. Oceanogr., 15(5), 688-694, 1970.

Hu, C., Chen, Z., Clayton, T., Swarzenski, P., Brock, J., and Muller-Karger, F.: Assessment of estuarine water-quality indicators using MODIS medium-resolution bands: Initial results from Tampa Bay, FL, Remote Sens. Environ., 93, 423-441, 2004.

Idso, S. and Gilbert, R.: On the universality of the Poole and Atkins Secchi disk-light extinction equation, J. Appl. Ecology, 11, 399401, 1974.

Jahnke, R. A.: Transport processes and organic matter cycling in coastal sediments, in: The global coastal ocean- Multi-scale interdisciplinary processes, edited by: Robinson, A. R. and Brink, K. H., pp. 163-191, Harvard University Press, Harvard, 2005.

Jahnke, R. A., Nelson, J. R., Marinelli, R. L., and Eckman, J. E.: Benthic flux of biogenic elements on the southeastern US continental shelf: influence of pore water advective transport and benthic microalgae, Cont. Shelf Res., 20, 109-127, 2000.

Jarrett, B. D., Hine, A. C., Halley, R., Naar, D. F., Locker, S. D., Neumann, A. C., Twichell, D., Hu, C., Donahue, B. T., Jaap, W. C., Palandro, D., and Ciembronowicz, K.: Strange bedfellows - a adep-water hermatypic coral reef superimposed ona drowned barrier island; southern Pulley Ridge, SW Florida platform margin, Marine Geology, 214(4), 295-307, 2005.

Jerlov, N. G.: Classification of sea water in terms of quanta irradiance, Journal International du Conseil pour l'Exploration de la Mer, 37, 281-287, 1977.

Johansson, G. and Snoeijs, P.: Macroalgal photosynthetic responses to light in relation to thallus morphology and depth zonation, Mar. Ecol. Prog. Ser., 244, 63-72, 2002.

Karl, D. M.: Microbiological oceanography - Hidden in a sea of microbes, Nature, 415(6872), 590-591, 2002.

Kayanne, H., Hata, H., Kudo, S., Yamano, H., Watanabe, A., Ikeda, Y., Nozaki, K., Kato, K., Negishi, A., and Saito, H.: Seasonal and bleaching-induced changes in coral reef metabolism and $\mathrm{CO}_{2}$ flux, Global Biogeochem. Cycles, 19, GB3015, doi:10.1029/2004GB002400, 2005.

Kühl, M. and Jørgensen, B. B.: Spectral light measurements in microphytobenthic communities with a fiber-optic microproble coupled to a sensitive diode array detector, Limnol. Oceanogr., 37, 1813-1823, 1992.

Kirkman, H.: Seagrasses of Australia, Australia: State of the Environment Technical Paper Series (Estuaries and the Sea), p. 36, 1997. 
Kleypas, J. A.: Modeled estimates of global reef habitat and carbonate production since the last glacial maximum, Paleoceanography, 12, 533-545, 1997.

Kleypas, J. A., McManus, J. W., and Meñez, L. A. B.: Environmental limits to coral reef development: where do we draw the line?, American Zoologist, 39(1), 146-159, 1999.

Klöser, H., Ferreyra, G., Schloss, I., Mercuri, G., Laturnus, F., and Curtosi, A.: Seasonal-variation of algal growth-conditions in sheltered Antarctic bays - the example of Potter Cove (King George Island, South Shetland), J. Mar. Syst., 4, 289-301, 1993.

Klumpp, D. W. and McKinnon, A. D.: Temporal and spatial patterns in primary production of a coral-reef epilithic algal community, J. Exp. Mar. Biol. Ecol., 131, 1-22, 1989.

Klumpp, D. W. and McKinnon, A. D.: Community structure, biomass and productivity of epilithic algal communities on the Great Barrier Reef: dynamics at different spatial scales, Mar. Ecol. Prog. Ser., 86, 77-89, 1992.

Larkum, A. W. D., Drew, E. A., and Crossett, R. N.: The vertical distribution of attached marine algae in Malta, J. Ecology, 55, 361-371, 1967.

Littler, M. M., Littler, D. S., Blair, S. M., and Norris, J. N.: Deepest known plant life discovered on an uncharted seamount, Science, 227, 57-59, 1985.

Lüning, K. and Dring, M. J.: Continuous underwater light measurement near Helgoland (North Sea) and its significance for characteristic light limits in the sublittoral region, Helgolander wiss. Meeresunters., 32, 403-424, 1979.

Maragos, J. E. and Jokiel, P.: Reef corals of Johnston Atoll: one of the world's most isolated reefs, Coral Reefs, 4, 141-150, 1986.

Maritorena, S., Siegel, D., and Peterson, A.: Optimization of a semianalytical ocean color model for global-scale applications, Appl. Opt., 41, 2705-2714, 2002.

Markager, S. and Sand-Jensen, K.: Light requirements and depth zonation of marine macroalgae, Mar. Ecol. Prog. Ser., 88, 8392, 1992.

Markager, S. and Sand-Jensen, K.: The physiology and ecology of light-growth relationship in macroalgae, in: Progress in Phycological Research, edited by: Round, F. E. and Chapman, D. J., pp. 210-266, Biopress Ltd., 1994.

Marks, K. M. and Smith, W. H. F.: An evaluation of publicly available global bathymetry grids, Mar. Geophys. Res., 27, 19-34, 2006.

Marra, J.: The compensation irradiance for phytoplankton in nature, Geophys. Res. Lett., 31(6), L06305, doi:10.1029/2003GL018881, 2004.

Martin, S., Clavier, J., Guarini, J.-M., Chauvaud, L., Hily, C., Grall, J., Thouzeau, G., Jean, F., and Richard, J.: Comparison of Zostera marina and maerl community metabolism, Aquatic Botany, 83, 161-174, 2005.

Masini, R., Cary, J., Simpson, C., and McComb, A.: Effects of light and temperature on the photosynthesis of temperate meadowforming seagrasses in Western Australia, Aquatic Botany, 49, 239-254, 1995.

Masuda, K., Goto, M., Maruyama, T., and Miyachi, S.: Photoadaptation of solitary corals, Fungia repanda, F. echinata, and their zooxanthellae, in: Proc. 7th Int. Coral Reef Symp., vol. 1, pp. 373-378, Guam, 1992.

McMinn, A., Hirawake, T., Hamaoka, T., Hattori, H., and Fukuchi, M.: Contribution of benthic microalgae to ice covered coastal ecosystems in northern Hokkaido, Japan, J. Mar. Biol. Assoc. UK, 85(2), 283-289, 2005.

Middelburg, J. J., Duarte, C. M., and Gattuso, J.-P.: Respiration in coastal benthic communities, in: Respiration in aquatic ecosystems, edited by: del Giorgio, P. A. and Williams, L. P. J., pp. 206-224, Oxford University Press, Oxford, 2005.

Miller, K. and Pearse, J.: Ecological studies of seaweeds in McMurdo Sound, Antarctica, American Zoologist, 31, 35-48, 1991.

Milliman, J. D. and Meade, R. H.: World-wide delivery of river sediment to the oceans, J. Geol., 91(1), 1-21, 1983.

Morel, A.: Optical modelling of the upper ocean in relation to its biogenous matter content (Case 1 waters), J. Geophys. Res., 93(C9), 10 749-10 768, 1988.

Morel, A., Antoine, D., and Gentili, B.: Bidirectional reflectance of oceanic waters: accounting for Raman emission and varying particle scattering phase function, Appl. Opt., 41, 6289-6306, 2002.

Morel, A. and Bélanger, S.: Improved detection of turbid waters from ocean color information, Remote Sens. Environ., 102, 237249, 2006.

Morel, A. and Gentili, B.: Diffuse reflectance of oceanic waters. 3. Implication of bidirectionality for the remote-sensing problem, Appl. Opt., 35, 4850-4862, 1996.

Morel, A. and Maritorena, S.: Bio-optical properties of oceanic waters: A reappraisal, J. Geophys. Res.-Oceans, 106, 7163-7180, 2001.

Morel, A. and Prieur, L.: Analysis of variations in ocean color, Limnol. Oceanogr., 22, 709-722, 1977.

Morel, A. and Smith, R. C.: Relation between total quanta and total energy for aquatic photosynthesis, Limnol. Oceanogr., 19(4), 591-600, 1974.

Nelson, J. R., Eckman, J. E., Robertson, C. Y., Marinelli, R. L., and Jahnke, R. A.: Benthic microalgal biomass and irradiance at the sea floor on the continental shelf of the South Atlantic Bight: spatial and temporal variability and storm effects, Cont. Shelf Res., 4, 477-505, 1999.

Nielsen, S. L., Borum, J., Geertz-Hansen, O., and Sand-Jensen, J.: Marine bundplanters dybdegrænse, Vand og Miljø, pp. 217-221, 1989.

Nielsen, S. L., Sand-Jensen, K., Borum, J., and Geertz-Hansen, O.: Depth colonization of eelgrass (Zostera marina) and macroalgae as determined by water transparency in Danish coastal waters, Estuaries, 25, 1025-1032, 2002.

Olesen, B., Enríquez, S., Duarte, C., and Sand-Jensen, K.: Depthacclimation of photosynthesis, morphology and demography of Posidonia oceanica and Cymodocea nodosa in the Spanish Mediterranean Sea, Mar. Ecol. Prog. Ser., 236, 89-97, 2002.

O’Reilly, J. E., Maritorena, S., Mitchell, B. G., Siegel, D. A., Carder, K. L., Garver, S. A., Kahru, M., and McClain, C.: Ocean color chlorophyll algorithms for SeaWiFS, J. Geophys. Res.Oceans, 103(C11), 24 937-24 953, 1998.

Overmann, J., Cypionka, H., and Pfenning, N.: An extremely lowlight-adapted phototrophic sulfur bacterium from the Black Sea, Limnol. Oceanogr., 37, 150-155, 1992.

Padilla, D. and Allen, B.: Paradigm lost: reconsidering functional form and group hypothesis in marine ecology, J. Exp. Mar. Biol. Ecol., 250, 207-221, 2000.

Pelevin, V. N. and Rutkovskaya, V. A.: On the optical classification of ocean waters from the spectral attenuation of solar radiation, 
Oceanology, 17, 28-32, 1977.

Pirc, H.: Seasonal aspects of photosynthesis in Posidonia oceanica: influence of depth, temperature and light intensity, Aquatic Botany, 26, 203-212, 1986.

Poole, H. and Atkins, W.: Photo-electric measurements of submarine illumination throughout the year, J. Mar. Biol. Assoc. UK, 16, 297-324, 1929.

Porter, J. W.: The maritime weather of Jamaica: its effect on coral productivity, 5th int. coral reef congress, 1985.

Reynolds, R., Rayner, N., Smith, T., Stokes, D., and Wang, W.: An improved in situ and satellite SST analysis for climate, J. Climate, 15, 1609-1625, 2002.

Richards, M., Jahnke, R. A., Nelson, J., Robertson, C., Rao, A., and Jahnke, D.: Predictability of benthic primary production using incident light on the South Atlantic Bight Seafloor, in: Ocean Sciences Meeting, p. (poster presentation), Hawaii, 2006.

Rivkin, R. and Putt, M.: Heterotrophy and photoheretrotrophy by Antarctic microalgae: light-dependent incorporation of amino acids and glusoce, J. Phycol., 24, 369-376, 1988.

Roberts, R. D., Kühl, M., Glud, R. N., and Rysgaard, S.: Primary production of crustose coralline red algae in a high Arctic fjord, J. Phycol., 38(2), 273-283, 2002.

Robinson, D., Arrigo, K., Iturriaga, R., and Sullivan, C.: Microalgal light-harvesting in extreme low-light environments in McMurdo Sound, Antarctica, J. Phycol., 31, 508-520, 1995.

Robinson, W., Franz, B., Patt, F., Baiey, S., and Werdell, P.: Masks and flags updates, in: Algorithm updates for the fourth SeaWiFS data reprocessing, NASA Technical Memorandum 2003206 892, vol. 22, edited by: Hooker, S. and Firestone, E., pp. 34-40, NASA Goddard Space Flight Center, Greenbelt, Maryland, 2003.

Rohmann, S., Hayes, J., Newhall, R., Monaco, M., and Grigg, R.: The area of potential shallow-water tropical and subtropical coral ecosystems in the United States, Coral Reefs, 24, 370-383, 2005.

Ruiz, J. and Romero, J.: Effects of in situ experimental shading on the Mediterranean seagrass Posidonia oceanica, Mar. Ecol. Prog. Ser., 215, 107-120, 2001.

Rysgaard, S., Nielsen, T. G., and Hansen, B. W.: Seasonal variation in nutrients, pelagic primary production and grazing in a high-Arctic coastal marine ecosystem, Young Sound, Northeast Greenland, Mar. Ecol. Prog. Ser., 179, 13-25, 1999.

Schwarz, A.-M., Hawes, I., Andrew, N., Norkko, A., Cummings, V., and Thrush, S.: Macroalgal photosynthesis near the southern global limit for growth; Cape Evans, Ross Sea, Antarctica, Polar Biol., 26, 789-799, 2003.

Schwarz, A.-M., Hawes, I., Andrew, N., Mercer, S., Cummings, V., and Thrush, S. F.: Primary production potential of nongeniculate coralline algae at Cape Evans, Ross Sea, Antarctica, Mar. Ecol. Prog. Ser., 294, 131-140, 2005.
Short, F. T.: Introduction to the special issue "Environmental impacts on seagrass", Aquatic Botany, 27, 1-2, 1987.

Silberstein, K., Chiffings, A. W., and McComb, A. J.: The loss of seagrass in cockburn sound, Western Australia. III. The effect of epiphytes on productivity of Posidonia australis Hook. F. Aquatic Botany, 24(4), 355-371, 1986.

Smith, S. V.: Coral-reef area and the contributions of reefs to processes and resources of the world's oceans, Nature, 273, 225226, 1978.

Spalding, H., Foster, M., and Heine, J.: Composition, distribution, and abundance of deep-water $(>30 \mathrm{~m})$ macroalgae in central California, J. Phycol., 39, 273-284, 2003.

Spalding, M., Ravilious, C., and Green, E. P.: World atlas of coral reefs, University of California Press, Berkeley, 2001.

Spalding, M. D. and Grenfell, A. M.: New estimates of global and regional coral reef areas, Coral Reefs, 16(4), 225-230, 1997.

Steneck, R.: Herbivory on coral reefs: a synthesis, in: Proc. 6th Int. Coral Reef Symp., vol. 1, pp. 37-49, Townsville, 1988.

Steneck, R. and Dethier, M.: A functional group approach to the strucutre of algal-dominated communities, Oikos, 69, 476-498, 1994.

Thuillier, G., Hersé, M., Labs, D., Foujols, T., Peetermans, W., Gillotay, D., Simon, P., and Mandel, H.: The solar spectral irradiance from 200 to $2400 \mathrm{~nm}$ as measured by the SOLSPEC spectrometer from the ATLAS and EURECA missions, Solar Physics, 214, 1-22, 2003.

Titlyanov, E., Cherbadgy, I., and Kolmakov, P.: Daily variations of primary production and dependence of photosynthesis on irradiance in seaweeds and seagrass Thalassodendron ciliatum of the Seychelles Islands, Photosynthetica, 31, 101-115, 1995.

Uthicke, S. and Klumpp, D. W.: Microphytobenthos community production at a near-shore coral reef: seasonal variation and response to ammonium recycled by holothurians, Mar. Ecol. Prog. Ser., 169, 1-11, 1998.

Vadas, R. L. and Steneck, R. S.: Zonation of deep water benthic algae in the gulf of Maine, J. Phycol., 24, 338-346, 1988.

Vörösmarty, C. J., Meybeck, M., Fekete, B., Sharma, K., Green, P., and Syvitski, J. P. M.: Anthropogenic sediment retention: major global impact from registered river impoundments, Global Planet. Change, 39, 169-190, 2003.

Weinberg, S.: Submarine daylight and ecology, Mar. Biol., 37, 291304, 1976.

Wessel, P. and Smith, W. H. F.: New, improved version of Generic Mapping Tools released, Eos, 79(47), 579, 1998.

Wethey, D. S. and Porter, J. W.: Sun and shade differences in productivity of reef corals, Nature, 262(5566), 281-282, 1976 